\title{
The melissopalynological investigation in the Eastern Dry Zone of Karnataka, India
}

${ }^{1}$ D.Shishira*, ${ }^{1 \& 2}$ A. R. Uthappa*, ${ }^{3}$ Veeresh Kumar, ${ }^{1}$ Shringeshwara, and ${ }^{1} \mathrm{G}$. C. Kuberappa,

1. University of Agricultural Sciences, GKVK, Bangalore

2. ICAR- Central Agroforestry Research Institute, Jhansi

3. ICAR- National Bureau of Agricultural Insect Resources, Bangalore

\section{Corresponding author: Shishira D.*}

\begin{abstract}
Melissopalynology, the analysis of pollen grains present in honey, indicates about the pollen and nectar sources in a region utilized by bees, which is used to determine the bee floral resources and botanical origin of the honey. This study investigated the melissopalynological analysis of the honey samples from the Eastern Dry zone of Karnataka. 24 honey samples were examined based on pollen analyses, among them 14 samples were unifloral, rest were multifloral. The unifloral honey had pollens of Callistemon viminalis, Areca catechu, Citrus sp., Mallotus philippensis, Cocos nucifera, Eucalyptus sp., Ocimum sp., Moringa oleifera and Pongamia pinnata. Samples collected in October, November, December, and January were rich in pollens of Eucalyptus sp.. Similarly, samples collected in January, February and March had pollen of tree species viz., Swietenia mahagoni, Canthium parviflorum, Simarouba glauca, Eucalyptus sp., Moringa oleifera, Syzygium cumini, Tabebuia sp., Pongamia pinnata, Acanthaceae, Anacardium occidentale, Cocos nucifera, Areca catechu, Mallotus philippensis, Bauhinia variegata, Psidium guajava, Alangiaceae, Euphorbiaceae, Ulmaceae, Capparis zeylanica, Convolvulaceae. GKVK-11 followed by GKVK-12 sample
\end{abstract}


recorded the highest Shannon diversity and GKVK-9 followed by GKVK-7 sample recorded the least diversity. Based on the similar floral composition samples were classified into four clusters. The PCA revealed that most of the samples grouped into a single cluster, except 7, 19, 20, 21, and 22 which were placed away from the origin. The presence of pollen in the honey of a particular plant species during different months is related to the blooming of that particular plant species from which the bees forage. The flora of honey changes with the season. The diversity of pollen grains in honey varied with location to location. The present study provides scientific knowledge to the beekeepers by indicating important plants for the development of the regional apiculture, through the identification of pollen types.

Keywords: Blooming period, Flora, Honey, Melissopalynology, Pollen

\section{Introduction}

Melissopalynology is a study of pollen grains present in honey. It helps to assess the bee floral availability of the region, where the particular types of honey are produced (Sajwani et al., 2007; Song et al., 2010). It also provides the exact information regarding the floral resource to bees in the vicinity and also becomes useful in the construction of the floral calendar (Sekhar, 2000).

The honey bees depend on the flora for nectar and pollen. The quality of honey varies concerning the flora available in and around them (Ponnuchamy et al., 2014). The Eastern dry zone of Karnataka is one of the important areas for beekeeping since the region comprises of a rich diversity of bee flora. One or the other flora bloom in every month which makes the bees survive throughout the year. The relative abundance of bee plants in the eastern dry zone consisted of trees (46\%), herbs (25\%), shrubs (18\%), trailers (9\%), climbers, and palms (2\%) (Marc, 
2012). The major bee flora available in and around the eastern dry zone region was Callistemon viminalis Byrnes, Anacardium occidentale L., Antigonon leptopus Hook. \& Arn., Simarouba glauca DC., Eucalyptus sp., Tabebuia sp. L., Cocos nucifera L., Mallotus philippensis Lour, Santalum album L., Tamarindus indica L., Trewia nudiflora L., and Bauhinia purpurea

L. (Sekhar, 2000).

The urban beekeeping industry is gaining popularity and is accepted as a complementary activity to agriculture in India (Attri, 2010). The analysis of the honey pollen spectrum is extremely useful to detect the contribution of different nectar sources during a different period of the year (Oliviera et al., 2010). It contributes to the development of the beekeeping industry by the way of proper utilization of floral resources and provides the exact information about the floral resources of the bees in the particular region. Melissopalynological studies are least touched in various parts of India, especially in South India (Jhansi et al., 1994). The studies on the source of pollen have been very few in Asia and with respect to different species of honey bees, the melissopalynological information available is very less (Ramalho et al., 2007 and Novais et al., 2009).

Although honey has been the most widespread bee product, the bee pollen trade is undergoing expressive growth. The quantity and quality of the bee pollen produced have attracted increased attention for Indian Apiculture. Eastern dry zone of Karnataka needs in-depth studies on the bee floras available also to support the interest of the urban beekeepers related to when is the honey flow season, dearth period, when to feed bees, when not to feed bees for managing the colonies. It also helps in developing the pollen spectrum through pollen combination. Henceforth, to encourage them and to make them aware of the floral calendar and the flora to which bee visits. This study aimed to identify the botanical origin of pollen loads and the melissopalynological investigation of Apis cerana honey in the Eastern dry zone of Karnataka. 
Materials and Methods

\section{Honey sampling and Melissopalynology}

Twenty-one honey samples (Tab.1) of Apis cerana were collected from different regions of the Eastern dry zone (Fig. 1) during 2016-17. A piece of Apis cerana comb completely sealed with honey was collected from different places and brought to the laboratory for extraction. The cut comb was unsealed using the uncapping knife, honey was extracted using a honey extractor, and the obtained honey thus filtered into a beaker using a muslin cloth and was transferred to an airtight container and was labeled concerned to the place, date and time of collection. The samples were stored in a refrigerator at $4^{\circ} \mathrm{C}$ for further studies (Method adopted from Saxena et al., 2010). After the complete removal of honey, the frame along with an empty comb was placed back to the same colony and the same position.

Apis cerana honey was analyzed for the presence of pollen using the acetolysis method suggested by Erdtman $(1952,1966)$. One gram of honey was diluted in $9 \mathrm{ml}$ of water and centrifuged at $4000 \mathrm{rpm}$ for $15 \mathrm{~min}$. The pollen so obtained at the bottom was collected, identified, and counted in all the 25 cells of hemocytometer under a microscope (Motic). Based on the percentage of each pollen type present in the honey was classified as unifloral (more than $45 \%$ of single pollen) or multifloral (less than $45 \%$ of single pollen) (Chaturvedi, 1989).

The grouping of honey is done by taking into account of pollen grains in $10 \mathrm{~g}$ honey following Maurizio's classes. Group I (20,000 pollen grains per $10 \mathrm{~g}$ honey), Group II (20,000-100,000 grains per 10 g honey), Group III (100,000500,000 grains per $10 \mathrm{~g}$ honey) (Louveaux et al., 1978). 
Table 1. List of samples examined and its location

\begin{tabular}{|c|c|c|c|c|}
\hline Sample No & Locality & Sample code & GPS Coordinates & Time of collection \\
\hline 1 & Baglur & Baglur-1 & $12.8304^{\circ} \mathrm{N}, 77.8662^{\circ} \mathrm{E}$ & July 2016 \\
\hline 2 & Baglur & Baglur-2 & $12.8304^{\circ} \mathrm{N}, 77.8662^{\circ} \mathrm{E}$ & July 2016 \\
\hline 3 & GKVK & GKVK-1 & $13.0797^{\circ} \mathrm{N}, 77.5808^{\circ} \mathrm{E}$ & July 2016 \\
\hline 4 & GKVK & GKVK-2 & $13.0797^{\circ} \mathrm{N}, 77.5808^{\circ} \mathrm{E}$ & August 2016 \\
\hline 5 & GKVK & GKVK-3 & $13.0797^{\circ} \mathrm{N}, 77.5808^{\circ} \mathrm{E}$ & August 2016 \\
\hline 6 & Yelahanka & Yelahanka-1 & $13.1155^{\circ} \mathrm{N}, 77.6070^{\circ} \mathrm{E}$ & September 2016 \\
\hline 7 & GKVK & GKVK-4 & $13.0797^{\circ} \mathrm{N}, 77.5808^{\circ} \mathrm{E}$ & September 2016 \\
\hline 8 & GKVK & GKVK-5 & $13.0797^{\circ} \mathrm{N}, 77.5808^{\circ} \mathrm{E}$ & October 2016 \\
\hline 9 & Baglur & Baglur-3 & $12.8304^{\circ} \mathrm{N}, 77.8662^{\circ} \mathrm{E}$ & October 2016 \\
\hline 10 & M S Palya & M S Palya-1 & $13.0813^{\circ} \mathrm{N}, 77.5483^{\circ} \mathrm{E}$ & November 2016 \\
\hline 11 & GKVK & GKVK-6 & $13.0797^{\circ} \mathrm{N}, 77.5808^{\circ} \mathrm{E}$ & November 2016 \\
\hline 12 & GKVK & GKVK-7 & $13.0797^{\circ} \mathrm{N}, 77.5808^{\circ} \mathrm{E}$ & December 2016 \\
\hline 13 & GKVK & GKVK-8 & $13.0797^{\circ} \mathrm{N}, 77.5808^{\circ} \mathrm{E}$ & December 2016 \\
\hline 14 & GKVK & GKVK-9 & $13.0797^{\circ} \mathrm{N}, 77.5808^{\circ} \mathrm{E}$ & December 2016 \\
\hline 15 & GKVK & GKVK-10 & $13.0797^{\circ} \mathrm{N}, 77.5808^{\circ} \mathrm{E}$ & December 2016 \\
\hline 16 & Baglur & Baglur-4 & $12.8304^{\circ} \mathrm{N}, 77.8662^{\circ} \mathrm{E}$ & December 2016 \\
\hline 17 & M S Palya & M S Palya-2 & $13.0813^{\circ} \mathrm{N}, 77.5483^{\circ} \mathrm{E}$ & January 2017 \\
\hline 18 & Yelahanka & Yelahanka-2 & $13.1155^{\circ} \mathrm{N}, 77.6070^{\circ} \mathrm{E}$ & February 2017 \\
\hline 19 & GKVK & GKVK-11 & $13.0797^{\circ} \mathrm{N}, 77.5808^{\circ} \mathrm{E}$ & March 2017 \\
\hline 20 & Baglur & Baglur-5 & $12.8304^{\circ} \mathrm{N}, 77.8662^{\circ} \mathrm{E}$ & March 2017 \\
\hline 21 & GKVK & GKVK-12 & $13.0797^{\circ} \mathrm{N}, 77.5808^{\circ} \mathrm{E}$ & March 2017 \\
\hline 22 & GKVK & GKVK-13 & $13.0797^{\circ} \mathrm{N}, 77.5808^{\circ} \mathrm{E}$ & April 2017 \\
\hline 23 & GKVK & GKVK-14 & $13.0797^{\circ} \mathrm{N}, 77.5808^{\circ} \mathrm{E}$ & May 2017 \\
\hline 24 & GKVK & GKVK-15 & $13.0797^{\circ} \mathrm{N}, 77.5808^{\circ} \mathrm{E}$ & June 2017 \\
\hline
\end{tabular}


The images of pollen collected from honey samples were captured by Moticam 2300 3.0M Pixel USB2.0 and the software used was Motica image plus 2.0 These pollen images were identified by making slides of available flora.

To study the similarity between the pollen sources agglomerative hierarchical clustering method was run using XLSTAT. The dendrogram was constructed using the Jaccard co-efficient and Unweighted pair group average method. PAST 3.24 version was used for principal component analysis (PCA) of the pollen data.

\section{Results}

Out of 24 samples analyzed, 15 were unifloral (62.5\%) with predominate pollen viz., Areca catechu L., Citrus sp., Mallotus philippensis Lour., Cocos nucifera L., Pongamia pinnata L., Ocimum sp., Casuarina equisetifolia L. each count $4.17 \%$ and Eucalyptus sp. alone was $33.33 \%$. Seven samples were identified as multifloral (37.50\%) (Figure 3).

The predominate families found in the samples are Acanthaceae, Convolvulaceae and Solanaceae(7.41\% each), Alangiaceae, Anacardiaceae, Arecaceae, Asteraceae, Bignoniaceae, Capparaceae, Casuarinaceae, Fabaceae, Iridaceae, Lamiaceae, Melastomataceae, Meliaceae, Moringaceae, Pedaliaceae, Piperaceae, Rubiaceae, Rutaceae, Sapotaceae, Simaroubaceae, Sterculiaceae and Ulmaceae(3.70\% each), Euphorbiaceae and Leguminosae (14.81\% each) and Myrtaceae count to $18.52 \%$ (Figure 4). The absolute pollen counts per $10 \mathrm{~g}$ of honey samples indicated that $50 \%$ of honey samples belong to the group I $(2,500-15,00$ pollen grains), $37.50 \%$ of samples belong to group II $(25,000-60,000)$ and $12.5 \%$ of samples belong to group III $(1,20,000-1,42,5000)$ (Table 2, Figure 5).

Plant pollen species present in the honey samples collected across the samples were A. auriculiformis, A. ilicifolius L., A. occidentale L., A. catechu, B. variegata Benth., Caesalpinia sp., C. viminalis Byrnes, C. parviflorum Roxb., C. zeylanica L., C. annum L., C. equisetifolia, Citrus sp., C. nucifera, C. pallida L., Eucalyptus sp., E. alsinoides L., M. philippensis, M. zapota (L.), M. oleifera L., Ocimum sp., P. hysterophorus L., P. pinnata L., P. guajava L., S. indicum DC., S. glauca, S. 
melongena L., S. multiflora Baill, S. mahagoni Lam., Syzygium cumini R.Br., and Tabebuia sp., and plant belonging to the family Sterculiaceae, Iridaceae, Myrtaceae, Alangiaceae, Acantheceae and Euphorbiaceae (Table 2, Figure 10-14).

The floral calendar of the melisopalynological studies (Figure 2) reveals that one or the other flora is available throughout the year in the Eastern Dry Zone of Karnataka. Samples collected in October, November, December, and January were rich in pollens of Eucalyptus. Similarly, samples collected in January, February to June had forest pollen species viz., S. mahagoni, C. parviflorum, S. glauca, Eucalyptus sp., M. oleifera, S. cumini R.Br., Tabebuia sp., P. pinnata, A. occidentals, C. nucifera, A. catechu, M. Philippensis, B. variegata, P. guajava, C. zeylanica, and plants belonging to the family Acanthaceae, Convolvulaceae, Alangiaceae, Euphorbiaceae, Ulmaceae.

To study the pollen diversity in the honey samples collected from different locations, Shannon diversity was determined. The diversity indices varied between 0 to 2.11 (Figure 6). Among the 24 different sources, the highest Shannon diversity was recorded in GKVK-11 followed by GKVK-12. The least diversity was recorded in GKVK-9 followed by GKVK-7. At 0.09 similarity co-efficient, data was classified into five clusters (Figure 7). Cluster 1 had an only sample (GKVK 1) which was unique since pollens (Citrus sp. and Sesamum indicum) found in this sample did not coincide with any other samples. Cluster 2 consisted of honey samples collected from locations viz., Baglur 1, Baglur 2, GKVK 15, Baglur 5, and GKVK 13. This cluster was mainly classified based on the presence of Swietenia mahagoni. The cluster 3 was the largest cluster comprising of 11 samples in which $81.82 \%$ were unifloral. Cluster 4 comprised of six location and their clustering in the same group is mainly due to similarity of tree species viz., Anacardium occidentale L., Bauhinia variegata L., Cocos nucifera and Mallotus philippensis. The cluster five had two samples (GKVK 4 and GKVK 12). The Principal Component analysis revealed that most of the samples grouped into a single cluster except $7,19,20$, and 21 which were placed away from the origin (Figure 8). The absolute pollen count and the frequency of each taxon are presented in Figure 9. 
Table 2. Melissopalynology data of honey samples collected in Eastern Dry region of Karnataka

\begin{tabular}{|c|c|c|c|c|c|}
\hline $\begin{array}{l}\text { Sample } \\
\text { code }\end{array}$ & $\begin{array}{c}\text { Pollen } \\
\text { count } / 10 g\end{array}$ & $\begin{array}{l}\text { Pollen } \\
\text { Groups }\end{array}$ & $\begin{array}{l}\text { Predominant } \\
\text { pollen type } \\
\text { (45\% and above) }\end{array}$ & $\begin{array}{l}\text { Secondary } \\
\text { pollen type } \\
(\mathbf{1 6 - 4 5 \% )}\end{array}$ & $\begin{array}{c}\text { Important } \\
\text { minor pollen } \\
\text { type }<15 \%\end{array}$ \\
\hline Baglur-1 & 15,000 & Group I & $\begin{array}{l}\text { Casuarina } \\
\text { equisetifolia }\end{array}$ & $\begin{array}{l}\text { Callistemon viminalis } \\
\text { Byrnes. }\end{array}$ & $\begin{array}{l}\text { Bauhinia variegata } \mathrm{L} \text {. } \\
\text { Suregada multiflora Baill, } \\
\text { Areca catechu L. }\end{array}$ \\
\hline Baglur-2 & 27,000 & Group II & Areca catech $u \mathrm{~L}$. & Cocos nucifera $\mathrm{L}$. & $\begin{array}{l}\text { Swietenia mahagoni Lam } \\
\text { Sterculiaceae }\end{array}$ \\
\hline GKVK-1 & 8000 & Group I & Citrus sp. & Sesamum indicum DC. & Unidentified 1 \\
\hline GKVK-2 & 9000 & Group I & & $\begin{array}{l}\text { Anacardium occidentale } \\
\text { L. }\end{array}$ & $\begin{array}{l}\text { Cocos nucifera } \mathrm{L} . \\
\text { Acanthus ilicifolius } \mathrm{L} . \\
\text { Caesalpinia } \mathrm{sp} .\end{array}$ \\
\hline GKVK-3 & 17000 & Group I & & $\begin{array}{l}\text { Anacardium } \\
\text { occidentale L., } \\
\text { Bauhinia variegata L. }\end{array}$ & Unidentified 2 \\
\hline Yelahanka-1 & 91000 & Group II & $\begin{array}{l}\text { Mallotus } \\
\text { philippensis Lour. }\end{array}$ & $\begin{array}{l}\text { Anacardium occidentale } \\
\text { L. }\end{array}$ & $\begin{array}{l}\text { Manilkara zapota } \mathrm{L} . \\
\text { Acacia } \mathrm{sp} ., \\
\text { Parthenium hysterophorus } \\
\mathrm{L} ., \\
\text { Solanum melongena } \mathrm{L} ., \\
\text { Psidium guajava } \mathrm{L} ., \\
\text { Cocos nucifera } \mathrm{L} ., \\
\text { Eucalyptus } \mathrm{sp} .\end{array}$ \\
\hline GKVK-4 & 69000 & Group II & Cocos nucifera $\mathrm{L}$. & Manilkara zapota & $\begin{array}{l}\text { Capsicum annuum } \mathrm{L} ., \\
\text { Capparis zeylanica } \mathrm{L} ., \\
\text { Psidium guajava } \mathrm{L} ., \\
\text { Melastomataceae, } \\
\text { Iridaceae(a), } \\
\text { Myrtaceae, }\end{array}$ \\
\hline
\end{tabular}




\begin{tabular}{|c|c|c|c|c|c|}
\hline & & & & & Alangiaceae, \\
\hline GKVK-5 & 9000 & Group I & Eucalyptus sp. & & $\begin{array}{l}\text { Anacardium occidentale } \\
\text { L. }\end{array}$ \\
\hline Baglur-3 & 23000 & Group II & Eucalyptus sp. & Solanum melongena $\mathrm{L}$. & $\begin{array}{l}\text { Moringa oleifera } \mathrm{L} . \\
\text { Alangiaceae, }\end{array}$ \\
\hline MS Palya-1 & 12000 & Group I & Eucalyptus sp. & Acacia $\mathrm{sp}$ & \\
\hline GKVK-6 & 16000 & Group I & Eucalyptus sp. & Pongamia pinnata $\mathrm{L}$. & $\begin{array}{l}\text { Three unidentified }(3,4 \& \\
5)\end{array}$ \\
\hline GKVK-7 & 170000 & Group III & Eucalyptus sp. & & Solanum melongena $\mathrm{L}$. \\
\hline
\end{tabular}

\begin{tabular}{|c|c|c|c|c|c|}
\hline GKVK-8 & 85000 & Group II & Eucalyptus sp. & $\begin{array}{l}\text { Areca catechu } \mathrm{L} . \\
\text { Simarouba glauca DC. }\end{array}$ & $\begin{array}{l}\text { Evolvulus alsinoides } \mathrm{L} ., \\
\text { Canthium parviflorum, } \\
\text { Solanum melongena } \mathrm{L} ., \\
\text { Cocos nucifera } \mathrm{L} ., \\
\text { Crotalaria pallida } \mathrm{L} ., \\
\text { Mallotus philippensis } \\
\text { Lour, } \\
\text { Iridaceae (b) } \\
\text { Myrtaceae }\end{array}$ \\
\hline GKVK-9 & 9000 & Group I & Eucalyptus sp. & & \\
\hline \begin{tabular}{|l|} 
GKVK-10 \\
\end{tabular} & 16000 & Group I & Eucalyptus sp. & & Sterculiaceae \\
\hline Baglur-4 & 19000 & Group I & Ocimum sp. L. & & $\begin{array}{l}\text { Eucalyptus sp. } \\
\text { Parthenium } \\
\text { hysterophorus L., } \\
\text { Callistemon viminalis } \\
\text { Byrnes }\end{array}$ \\
\hline
\end{tabular}




\begin{tabular}{|c|c|c|c|c|c|}
\hline MS Palya-2 & 14000 & Group II & & Moringa oleifera $\mathrm{L}$. & $\begin{array}{l}\text { Anacardium occidentale } \\
\text { L.,Cocos nucifera L., } \\
\text { Areca catechu L., } \\
\text { Mallotus philippensis } \\
\text { Lour, } \\
\text { Acanthaceae, }\end{array}$ \\
\hline Yelahanka-2 & 110000 & Group III & & Syzygium cumini R.Br. & $\begin{array}{l}\text { Bauhinia variegata } \mathrm{L} . \\
\text { Anacardium occidentale } \\
\text { L., } \\
\text { Mallotus philippensis } \\
\text { Lour, } \\
\text { Psidium guajava L., } \\
\text { Alangiaceae } \\
\text { Unidentified (6) }\end{array}$ \\
\hline GKVK-11 & 168000 & Group III & & $\begin{array}{l}\text { Pongamia pinnata } \mathrm{L} . \\
\text { Canthium parviflorum } \\
\text { Lamk, } \\
\text { Simarouba glauca } \text { DC., } \\
\text { Eucalyptus sp., } \\
\text { Unidentified } 7\end{array}$ & $\begin{array}{l}\text { Syzygium cumini R.Br., } \\
\text { Tabebuia sp. L., } \\
\text { Mallotus philippensis } \\
\text { Lour, } \\
\text { Euphorbiaceae }\end{array}$ \\
\hline Baglur-5 & 38000 & Group II & & $\begin{array}{l}\text { Pongamia pinnata L., } \\
\text { Tabebuia } \text { sp. L., } \\
\text { Moringa oleifera L., } \\
\text { Swietenia mahagoni } \\
\text { Lam. } \\
\text { Unidentified } 8\end{array}$ & \\
\hline GKVK-12 & 53000 & Group II & & Pongamia pinnata $\mathrm{L}$. & $\begin{array}{l}\text { Cocos nucifera } \mathrm{L} ., \\
\text { Mallotus philippensis } \\
\text { Lour, } \\
\text { Capparis zeylanica } \mathrm{L} \text {. } \\
\text { Convolvulaceae, } \\
\text { Ulmaceae, } \\
\text { Unidentified }(9,10,11 \& \\
12)\end{array}$ \\
\hline GKVK-13 & 12,137 & Group I & $\begin{array}{l}\text { Pongamia } \\
\text { pinnata } \mathrm{L} .\end{array}$ & & $\begin{array}{l}\text { Swietenia mahagoni, } \\
\text { Parthenium hysterophorus } \\
\text { L. }\end{array}$ \\
\hline
\end{tabular}


bioRxiv preprint doi: https://doi.org/10.1101/2020.07.06.189274; this version posted July 6,2020 . The copyright holder for this preprint (which was not certified by peer review) is the author/funder, who has granted bioRxiv a license to display the preprint in perpetuity. It is made available under aCC-BY 4.0 International license.

\begin{tabular}{|l|l|l|l|l|l|}
\hline GKVK-14 & \multirow{2}{*}{16075} & Group II & & $\begin{array}{l}\text { Cocos nucifera, } \\
\text { Tabebuia } \text { sp., } \\
\text { Anacardium occidentale } \\
\text { L. }\end{array}$ & \\
\hline GKVK-15 & 8500 & Group I & & $\begin{array}{l}\text { Swietenia mahagoni } \\
\text { Lam, } \\
\text { Areca catech } u \text { L. }\end{array}$ & \\
\hline
\end{tabular}




\section{Discussion and Conclusion}

The presence of pollens in honey symbolized the bee foraging plants. Among several flowering plants bee forage specific plants (Dimou, 2007). The diversity of pollen grains in honey varied with locations and availability of bee flora (Song et al., 2014). The present study provides a vision on the pollen spectrum of the Eastern dry zone of Karnataka. Overall, 51 pollen taxa from 24 honey samples were recorded from the study. A total of 80 pollens were recorded from 42 samples in Tropical South India and 61 pollen from 19 samples from the central region of Shanxi (Ponnuchamy et al., 2014; Song et al., 2012). The pollens from the Eastern dry zone of Karnataka are Callistemon viminalis Byrnes, Areca catechu L., Citrus sp. L., Mallotus philippensis Lour., Cocus nucifera L., Eucalyptus sp. Labill., Ocimum sp. L., Moringa oleifera L., and Pongamia pinnata L., Swietenia mahagoni Lam., Canthium parviflorum, Simarouba glauca DC., Eucalyptus sp., Syzygium cumini R. Br., Tabebuia sp. L., Acanthaceae, Anacardium occidentals L., Bauhinia variegata L., Psidium guajava L., and Capparis zeylanica L. Similarly, in Brazil, Eucalyptus sp. and Citrus sp. were predominant (Barth, 1970: Ramlho et al., 1991). In India, honey from Uttar Pradesh predominated with pollen from Antegonon and Moringa (Nair and Singh, 1974), Rumex sp., Nephelium sp., and members of Myrtaceae, Liliaceae, Rosaceae, and Euphorbiaceae (Sharma and Nair, 1965; Gaur and Nanwani, 1989). Honey from Himachal Pradesh had a preponderance of Brassica, Adathoda, Clematis, Mussenda, and Helianthus sp. (Singh et al., 1994). Honey from Andhra Pradesh revealed that Sapindus, Eucalyptus, Anacardium, and Cleome were major pollen types (Kalpana and Ramanujan, 1997). In Karnataka, honey samples were having pollens from Cocos, Eucalyptus, Schefflera, and Mimosa (Singh and Suryanarayana, 1990). Also, the Samples collected in October, November, December, and January were rich in pollens of Eucalyptus. Many Eucalyptus species offer pollen and nectar to the pollinators (House, 1997). In the many tropical to subtropical regions, where Eucalyptus species have been planted, and often become naturalized, they have become important, or even dominant, nectar sources for beekeeping in southern Asia (Chauhan et al., 2017), in South America (Daners, 1998; Bonilla et al., 2016), in Africa (Carroll, 2006) and other tropical regions (Rasoloarijao, 2014), and many 
countries within the Mediterranean Basin (Seijo et al., 2003; Terrab et al., 2003; Fea's et al., 2010). Similarly, in January, February and March had forest pollen species viz., Pongamia, Syzygium, Santalum, Neem, Mahagoni, etc. The presence of pollen in the honey of particular plant species during different months is related to the blooming of that particular plant species from which the bees collected the pollen during foraging activity (Joshi et al., 1998). They have reported that the major honey sources were Bombax, Lannea, Limonia, Moringa, Peltoforum, Pongamia, Syzygium, and Tamarindus during major honey flow season (FebruaryJuly) and the pollens of Eucalyptus and Alternanthera were predominant during minor honey flow season (September-December).

The results of this work also reveal that $62.5 \%$ of the honey samples are unifloral and the remaining $37.5 \%$ are multifloral and the floral type of honey was confirmed by the absolute pollen count. From the Leon and Palenica provinces out of 89 honey samples 51.69\% was unifloral (Herrero et al., 2001). The quality and quantity of the bee pollen produced and the floral type help in increasing the market value of honey.

A floral calendar is developed with month-wise bee foraging plants with the classifying groups viz., major pollens, secondary pollen, and minor pollen types. This will help farmers and beekeepers to educate about the flora available and establish the apiary.

Shannon diversity indices are used to classify the samples based on their spatial location and to gather knowledge about the dynamics of preference toward the foraging plant (Ponnuchamy et al., 2014). High values of Shannon diversity indices in samples GKVK-11 and GKVK-12 indicates rich nectar and pollen sources in GKVK location in March. The Shannon-Weaver diversity index was varying from 1.79 to 2.21 in the samples from the Central region of Shanxi, North China (Song et al., 2012). Some of the locations had similar pollen compositions based on which the cluster analysis is plot. From the statistical analysis of cluster analysis, the samples are grouped into five clusters. This result is in accordance with the four clusters formed out of 89 samples which were collected from the Leon and Palenica provinces (Herrero et al., 2001). This is based on the common pollen taxa recorded in different months. Eucalyptus sp. L was predominant in 
samples of cluster 4. GKVK 1 recorded unique compared to other cluster; this may be due to Sesamum and Citrus, generally, Sesamum isn't grown in the Eastern dry zone of Karnataka and few experimental plots of GKVK campus of UAS, Bangalore, had Sesamum which reflected in GKVK 1 sample. Majority samples in cluster 3 are unifloral and cluster 4 are multifloral. Based on this study, honey samples are grouped according to their botanical origin.

The grouping in PCA might be due to pollen diversity, the season of collection and abundance or dearth period (Sekhar, 2000). This was reflected in PCA plots wherein a few samples $(7,19,20,21)$ were distributed away from the origin (Fig. 8). Since most of the tree species in the study location bears flowers in February and March, the honey bees had the opportunity to explore the diverse flora and collect pollens of different tree species. It was also observed that samples that had pollens from more than 5 species might have been placed away from the origin. It can be observed that the time of sampling would have affected the pollen variability in the honey sample (Marc, 2012; Raja, 2012). Among these samples, $75 \%$ were multifloral and were sampled during March.

Overall, this study provides useful data regarding the favoured plant and the foraging preference of Apis cerana from the Eastern dry zone of Karnataka, which will help beekeepers to develop the apiary. It provides information regarding the agricultural crop which gets pollinated and can be utilized for pollination purposes. This study will in-turn contribute to the conservation of bees, apiary development and leads to sustainable honey production. Also, this will improve the socioeconomic status of the farmers and beekeepers.

\section{Acknowledgement}

We are sincerely thankful to Dr. Bhat, Mrs. Eshwarappa G. C., Dr. Vijayakumar KT for providing valuable guidance throughout the project.

\section{References}

Attri PK. Melissopalynological investigations on Apis cerana autumn honey collected from Chamba District of the Himachal Pradesh. International Journal of 
Science and Nature. 2010; 1: 67-72.

Barth OM. Análisemicroscópica de algumasamostras de mel.1- pólen dominante. Anais da Academia Brasileira de Ciências. 1970; 42: 351-366.

Carroll T. A Beginner's Guide to Beekeeping in Kenya. Nairobi. Legacy Books; 2006.

Chaturvedi M. Pollen analysis of some spring honeys from the western Himalayan region of Uttar Pradesg, India. Proceedings of the Indian Academy of Sciences, Plant Sciences. 1989; 99: 241-246.

Chauhan MS, Farooqui A, and Trivedi A. Plants foraged by bees for honey production in northern India: The diverse flora of India and its implications for apiculture. Acta Palaeobotanica. 2017; 57:119-32.

Daners G, and Tellerı'a MC. Native vs. introduced bee flora: a palynological survey of honeys from Uruguay. Journal of Apicultural Research. 1998; 37:2219.

Dimou $M$ and Thrasyvoulou A. Seasonal variation in vegetation and pollen collected by honeybees in Thessaloniki, Greece. Grana. 2007; 46: 292-299.

Erdtman G. Pollen morphology and plant taxonomy of Angiosperm. Chronica Botanica Co., Waltham, Massachusettes; 1952.

Erdtman G. Pollen morphology and plant taxonomy of Angiosperm. An introduction of palynology revised edition, Hanerphtb. Co. New York, London; 1966. 
Fea's X, Pires J, Estevinho M L, Iglesias A, Pinto de Araujo JP. Palynological and physicochemical data characterisation of honeys produced in the Entre-Douro e Minho region of Portugal. International Journal of Food Science and Technology. $2010 ; 45: 1255-62$.

Gaur RD and Nanwani P. A melitopalynological analysis of apiary honey from Pauri Garhwal, Uttar Pradesh, India. Indian Bee J. 1989; 51: 12-14.

Herrero B., Valencia-Barrer RM, Martin RS and Pando V. Characterization of honeys by melissopalynology and statistical analysis. Canadian Journal of Plant Science. 2002; 82: 75-82.

House SM. Reproductive biology of eucalypts. In: Williams J, Woinarski J, editors. Eucalypt Ecology: Individuals to Ecosystems. Cambridge: Cambridge University Press; 1997. pp. 30-55.

Jhansi P, Kalpana TP and Ramanujam CGK. Pollen analysis of some Apis cerana Fab. Honeys from Andhra Pradesh, India. Apidologie. 1994; 25: 289-296.

Joshi MA, Lakshmi K, and Suryanarayana MC. Melittopalynological investigations on Apis and Trigona honeys collected in and around Pune, Maharashtra. Indian Bee Journal, 1998; 60: 90- 98.

Kalpana TP, and Ramanujan CGK. Melittopalynology, bee plants and beekeeping potential in some coastal districts of Andra Pradesh, India. Indian Bee J. 1997; 59: $1-8$.

Louveaux J, Maurizio A. and Vorwohl G. (1978) Methods of melissopalynology. Bee World, 59: 139-157. 
Marc N. Melissopalynological studies of $A$. cerena indica F. in North Bangalore region, M.Sc. Thesis, University of Agricultural Sciences, Bangalore, India. 2012; "Forthcoming".

Mattu VK, and Verma LR. Studies on annual foraging cycle of ApisceranaF. in Simla hills of North-West Himalaya. Apidologie, 1997; 16: 1-18.

Mendes E., Brojo P. E., Ferreira I. M. P. L. V. O. and Ferreira M. A. (1998) Quality evaluation of Portuguese honey. Carbohydrate Polymers, 37: 219-223.

Nair PK. and Singh KN. A study of two honey plants, Antegonan leptopus Hook and Mrtinga pterigosperma Gaetrn. Indian J. Hort. 1974; 31: 375-379.

Novais Js De , L Cristina Lima e Lima and Francisco de Assis Ribeiro dos Santos. Botanical affinity of pollen harvested by Apis mellifera L. in a semi-arid area from Bahia, Brazil, Apidologie. 2009; 48: 224-234.

Ortega-Bonilla RA, Chito-Trujillo DM, Sua'rez-Ramos CA. Physicochemical characteristics of commercial eucalyptus honeys from Southwest Casanare. Corpoica Cienca y Tecnolog'1a Agropecuaria (Colombia), 2016; 17:73-80.

Oliveira PP., Van Den Berg C, Santos-Grana FDARD. Pollen analysis of honeys from Caatinga vegetation of state of Bahia, Brazil. Taylor \& Francis Online. 2010; 49: 66-75.

Ponnuchamy R, Bonhomme V, Prasad S, Das L, Patel P, et al. Honey pollen: Using melissopalynology to understand foraging preferences of bees in Tropical South India. Plosone. 2014; 9(7).

Ramachandra TV, Bharath H Aithal and Durgappa DS. Insights to urban dynamics 
through landscape spatial pattern analysis. Int. J Applied Earth Observation and Geo-information. 2012; 18: 329-343.

Ramalho M, Guibu LS, Giannini TC, Kleinert A and Imperatriz VL. Characterization of some Southern Brazilian honey and bee plants through pollen analysis. J. Apic. Res. 1991; 30: 81-86.

Rasoloarijao TM, Ramamonjisoa Ralalaharisoa Z, Ramavovololona P, Porphyre V. Analyse pollinique des miels des ^1les de l'Oce'an Indien. Revue d'e'levage et de me'decine ve'te'rinaire des pays tropicaux. 2014; 67: 128-9. 28.

Sajwani A, Farooq SA, Patzelt A, Eltayeb EA, Bryant VM. Melissopalynological studies from Oman. Palynology. 2007; 31: 63-79.

Saxena S, Gautam S, Sharma A. Physical, biochemical and antioxidant properties of some Indian honeys. Food Chem. 2010; 118: 391-397.

Seijo MC, Aira MJ, Me'ndez J. Palynological differences in the pollen content of Eucalyptus honey from Australia, Portugal and Spain. Grana. 2003; 42:183-90.

Sekhar P. Melissopalynological studies of A. cerena indica F. in Bangalore region, M.Sc.Thesis, University of Agricultural Sciences, Bangalore, India. 2000; "Forthcoming".

Sharma M and Nair PKK. Pollen analysis of some honey from Uttar Pradesh. Indian J. Hort. 1965; 22: 46-51. 
Singh P, Verma LR and Mattu VK. Pollen spectrum of come honey of the North East Himalayas as a determinant of honey bee forage. Indian Bee J. 1994; 56: 3752.

Song XY, Yang YF and Yang WD. Pollen analysis of natural honeys from the central region of Shanxi, North China. Plos One. 2012; 7(11).

Suryanarayana MC, Mohan Rao and Singh TSMS. Coconut- Arecaceae - a pollen and nectar sources to honey bees. Indian Bee J. 1997; 52: 41-43.

Terrab A, D1'ez MJ, Heredia FJ. Palynological, physico-chemical and colour characterization of Moroccan honeys: I. River red gum (Eucalyptus camaldulensis Dehnh) honey. International Journal of Food Science and Technology. 2003; 38: $379-386$.

Upadhyay D, Bhattacharya S, Ferguson DK, and Bera S. Prospects of Apicultural Entrepreneurship in Coastal Districts of Eastern India:A Melissopalynological Evaluation. Plos One 2014; 9(4): e94572. doi:10.1371/journal.pone.0094572

http://dx.doi.org/10.1016/j.jag.2012.03.005. 


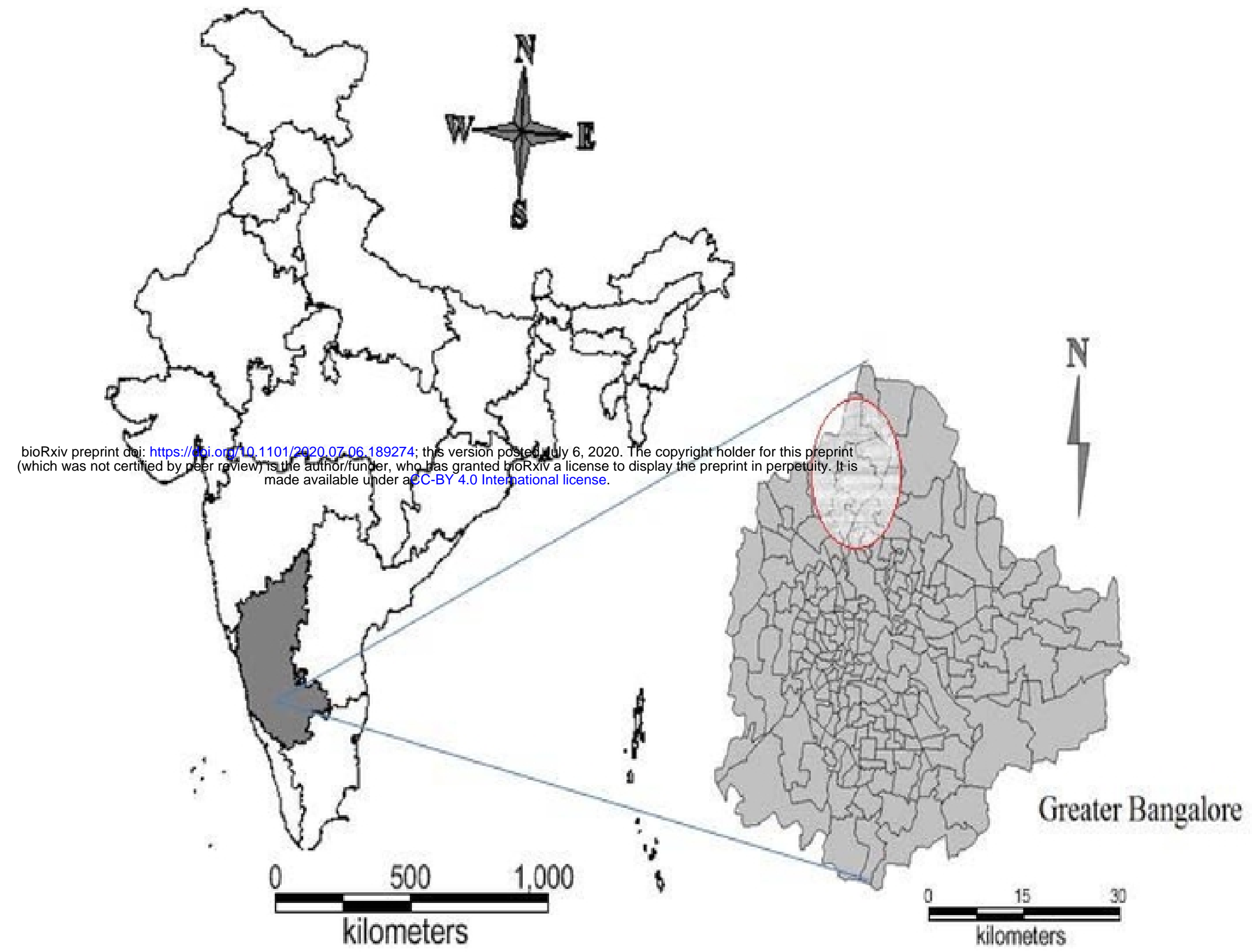

Figure 1. Location map showing the study area. (Left) map showing the position of Karnataka, (Right) map showing the sampling sites in the Bangalore region of Karnataka. 


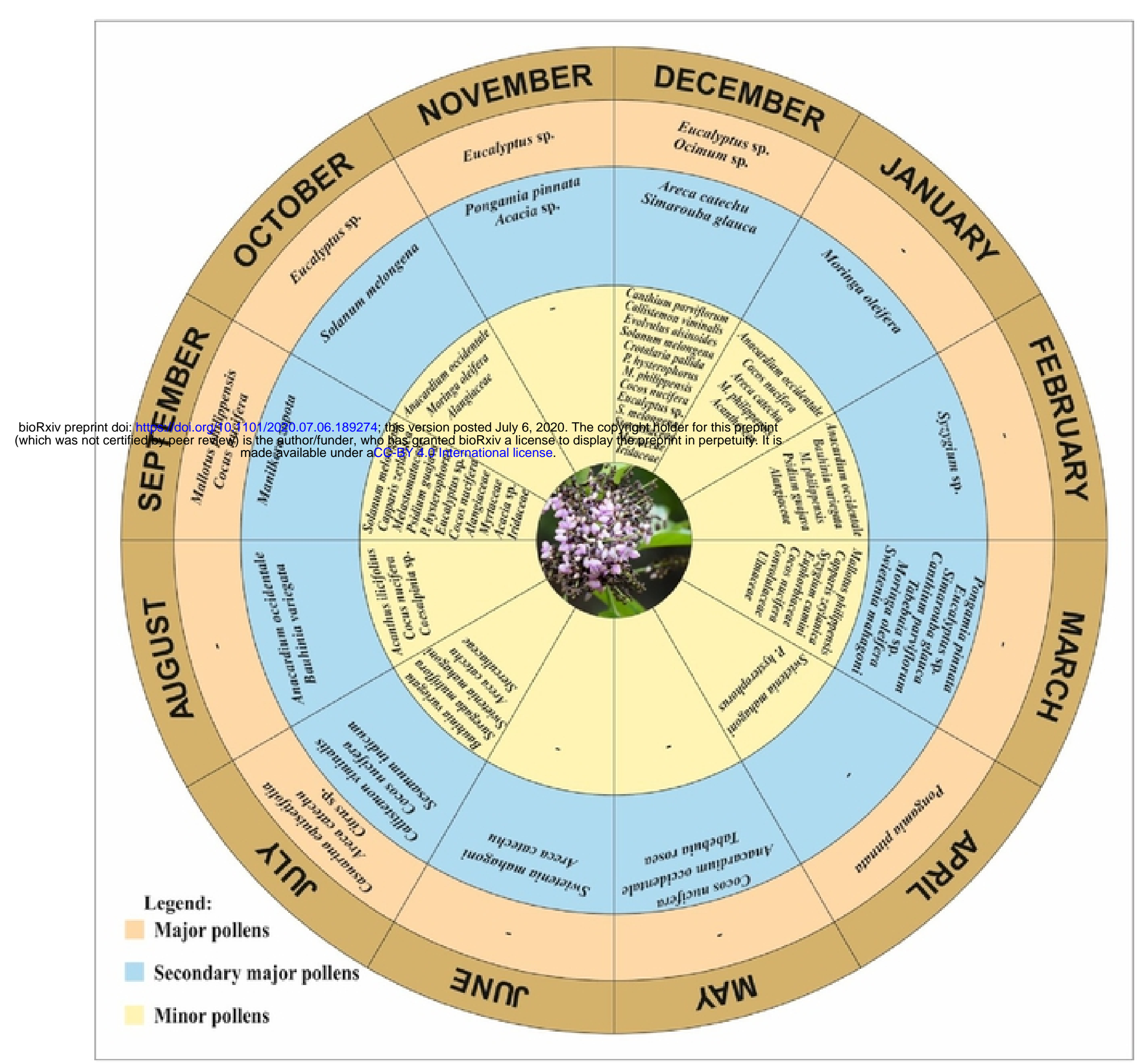

Figure 2: Floral Calender of A.cerana Fab. in Eastern Dry Zone of Karnataka. 


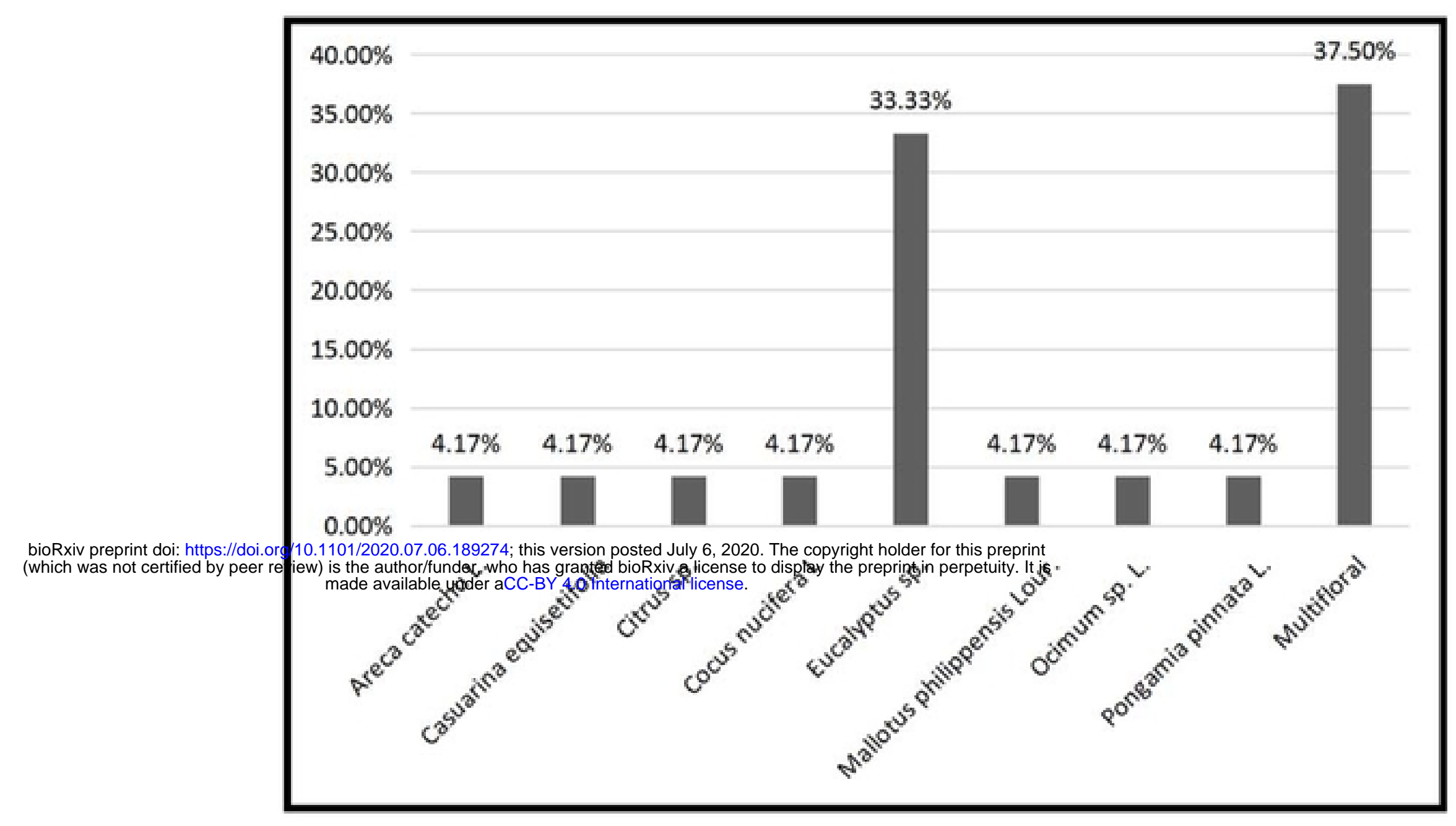

Figure 3: Floral nature of honey samples of Apis cerana collected from the Eastern dry zone of

Karnataka are Areca catechu, Citrus sp., Mallotus philippensis, Cocus nucifera, Simarouba glauca, Ocimum sp., Casuarina equisetifolia each counts $4.17 \%$, Eucalyptus $\mathrm{sp}$. counts $33.33 \%$ and 9 samples were multifloral $(37.50 \%)$

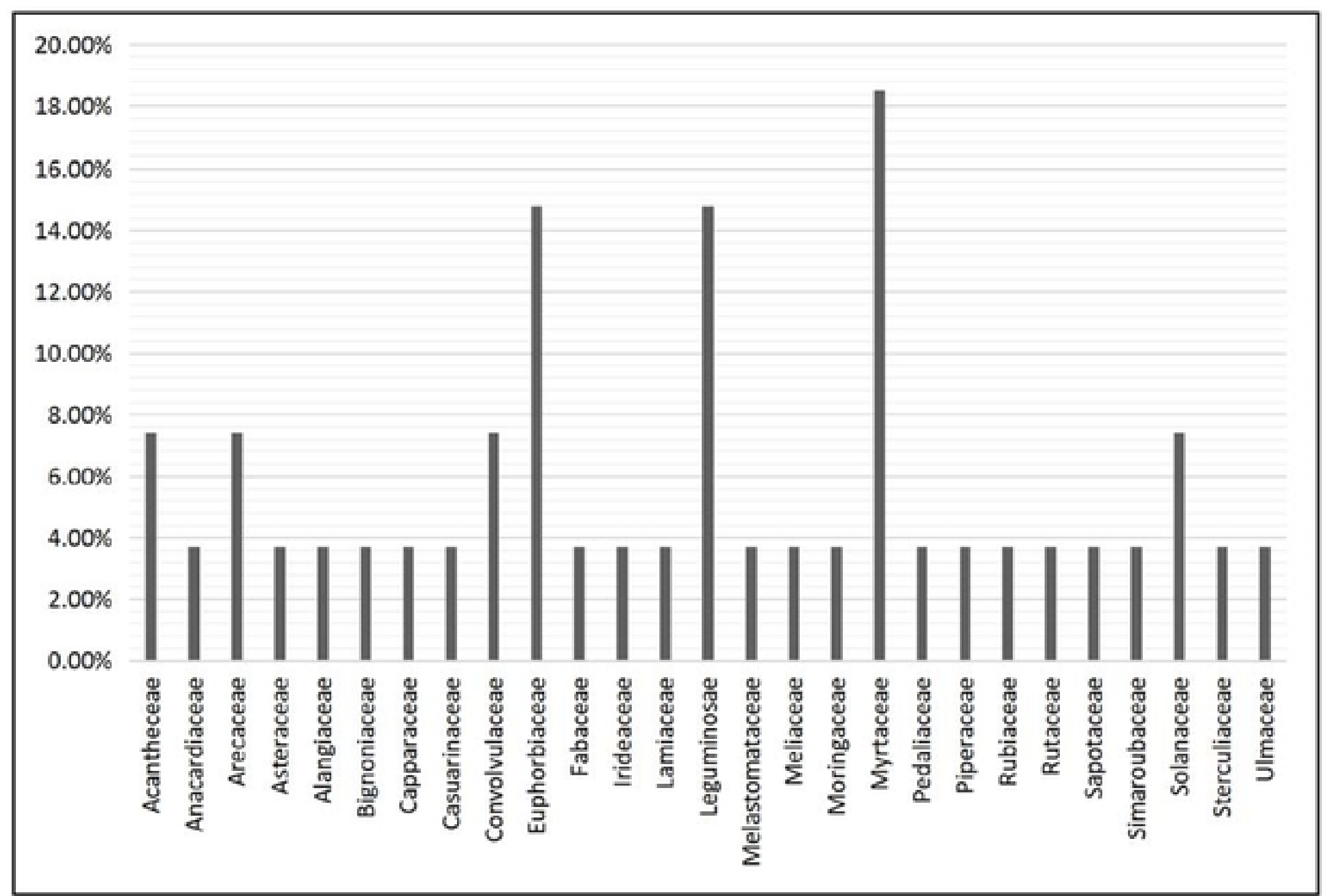

Figure 4: Families found in the honey samples of Apis cerana collected from the Eastern dry region. 


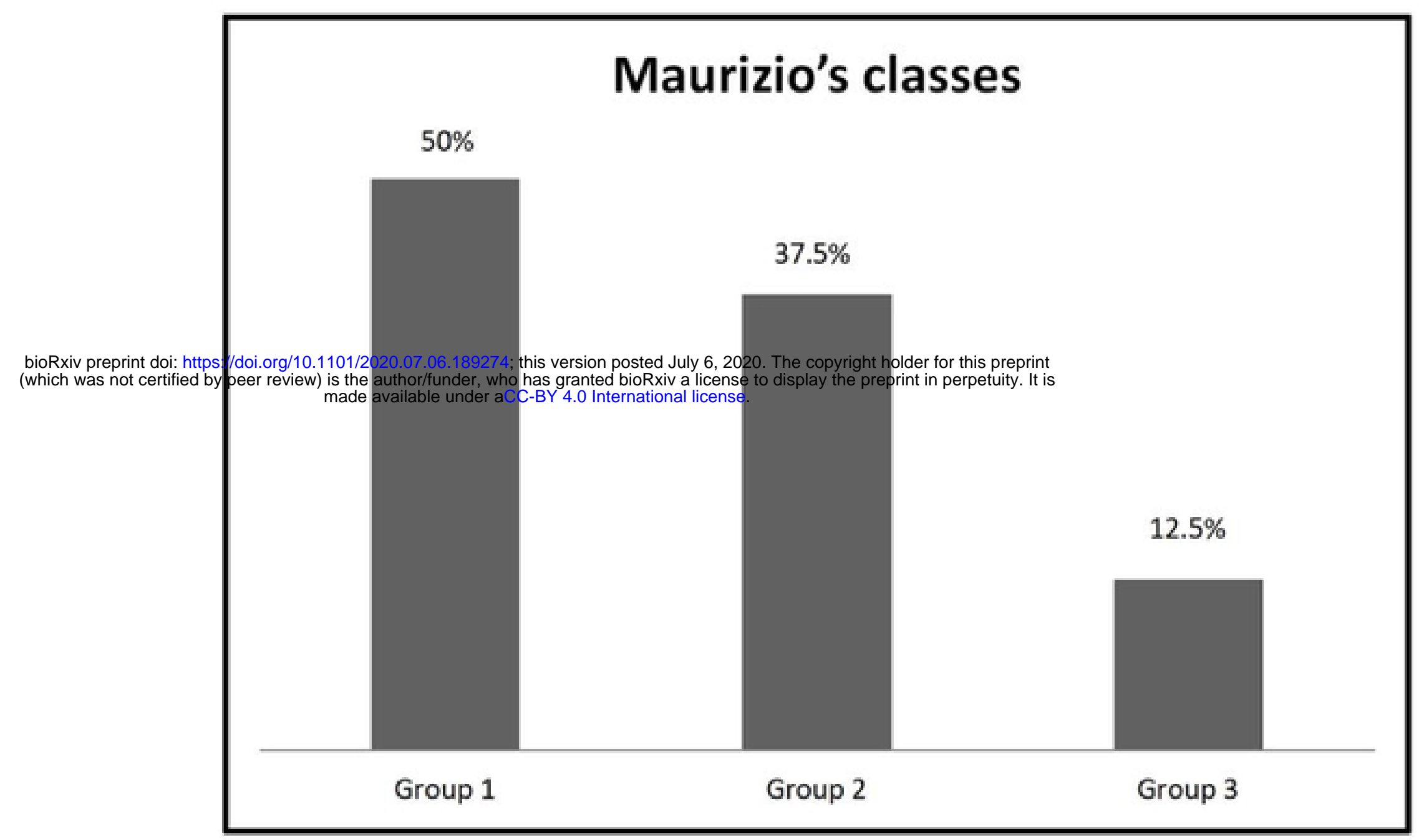

Figure 5. Distribution (\%) of the honey samples according to Maurizio's classes. Group I $(<20,000$ pollen grains per $10 \mathrm{~g}$ honey) found in 12 samples $(50 \%)$, Group II $(20,000-100,000$ grains per $10 \mathrm{~g}$ honey) found in 9 samples $(37.50 \%)$, Group III $(100,000-500,000$ grains per $10 \mathrm{~g}$ honey) found in 3 samples (12.5\%) 


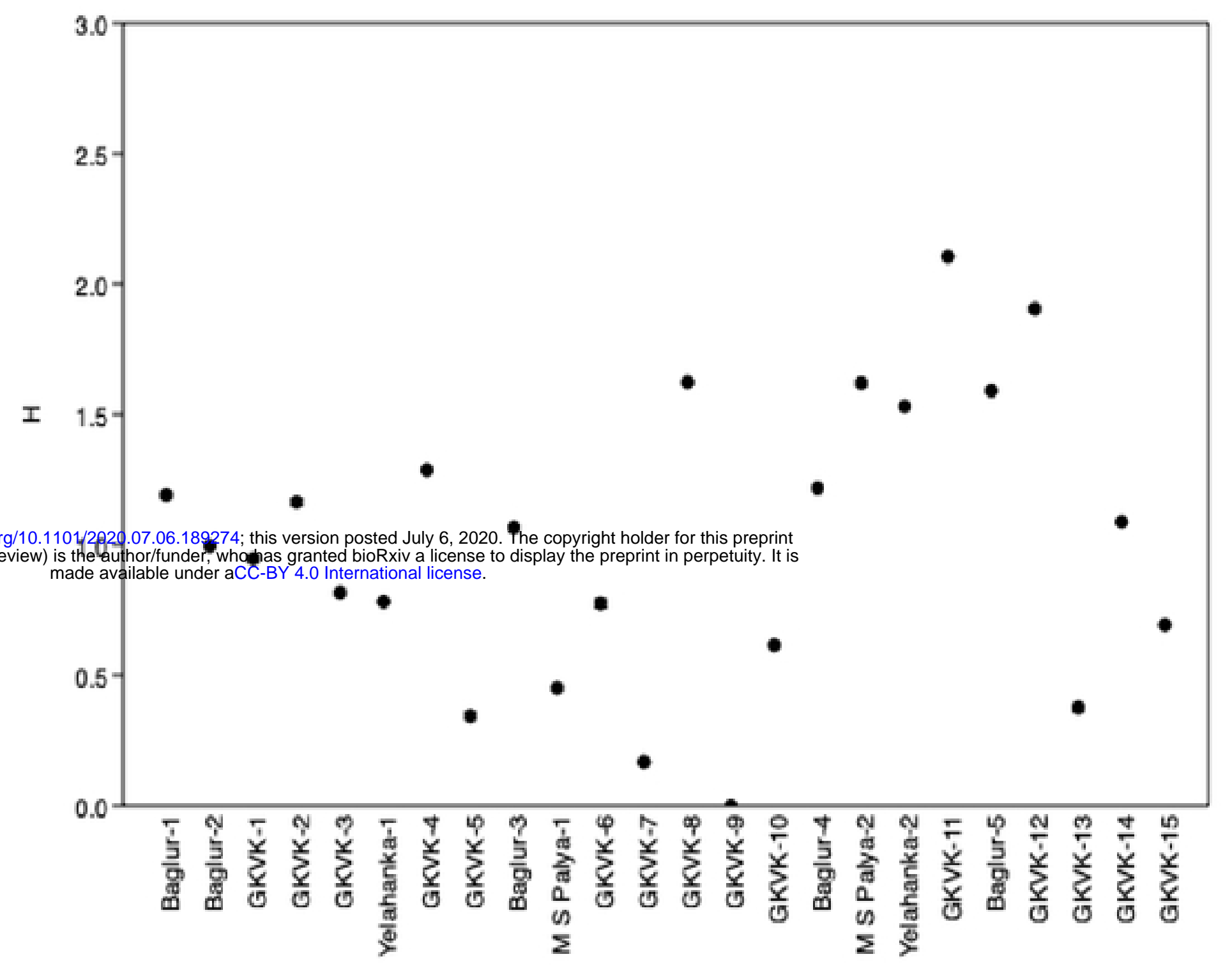

Figure 6: Diversity indices of the pollen samples 


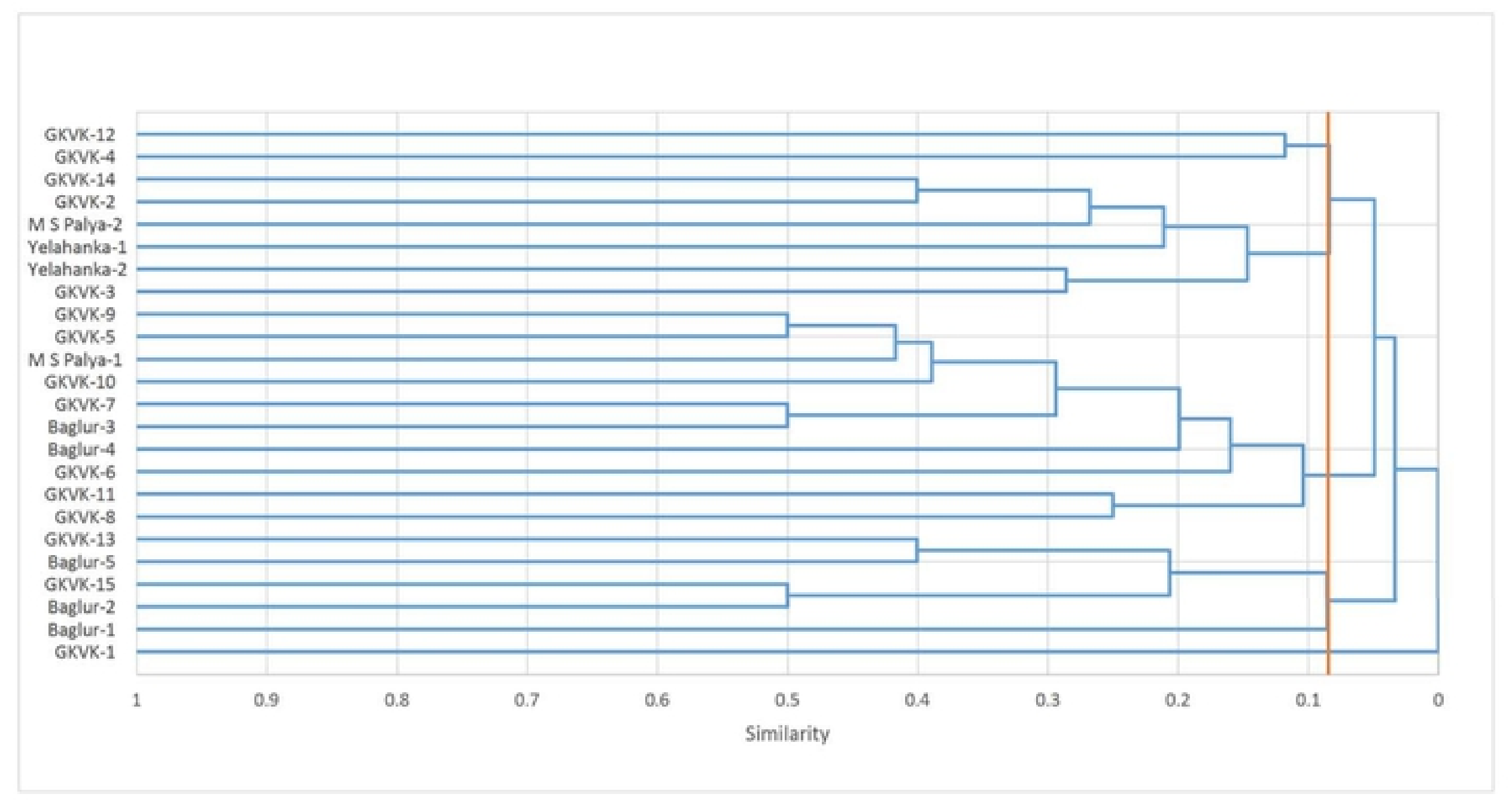

Figure 7: Cluster analysis of absolute pollens collected from the eastern dry zone 


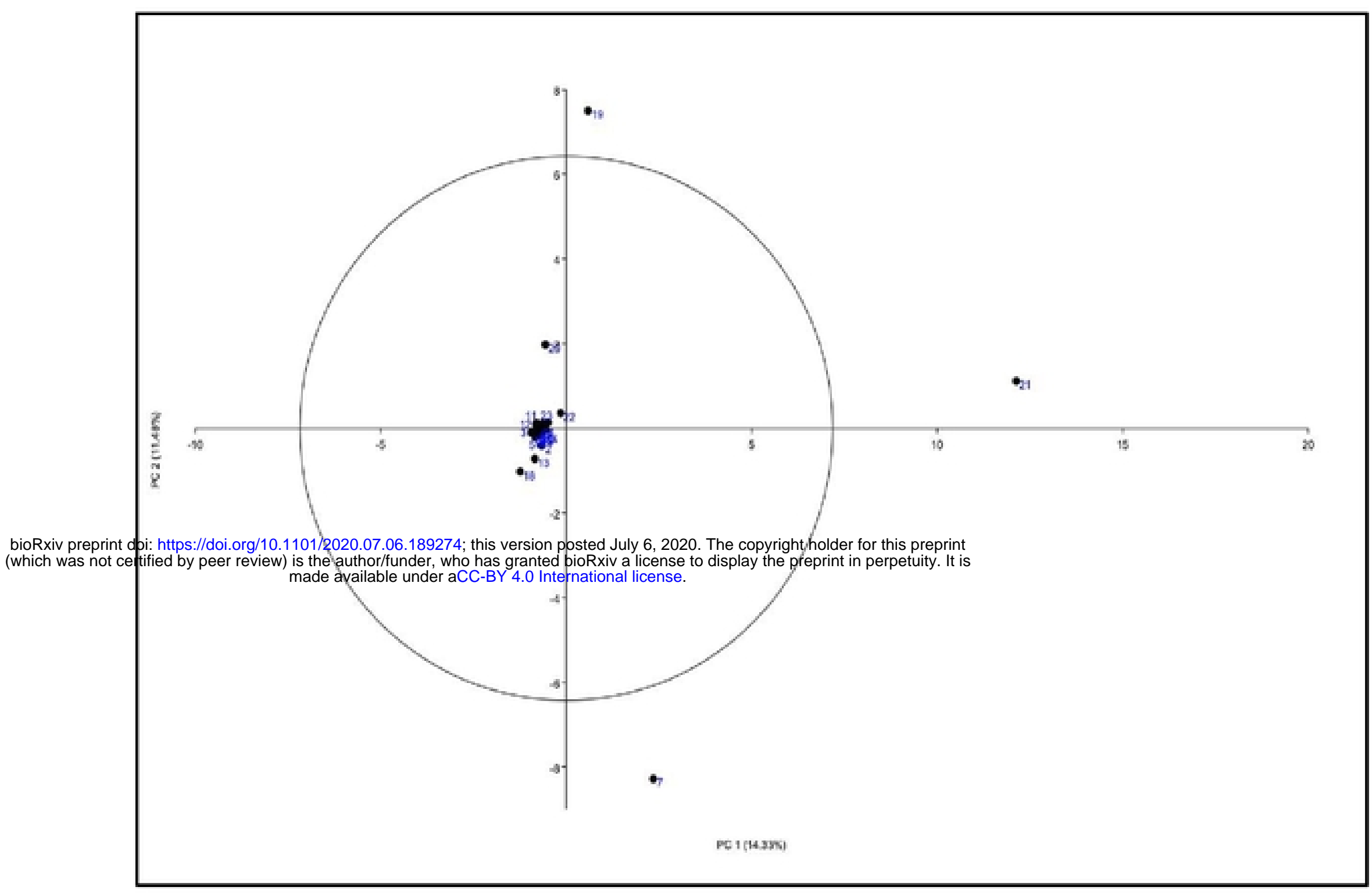

Figure 8: Principal component analysis using absolute pollen count 


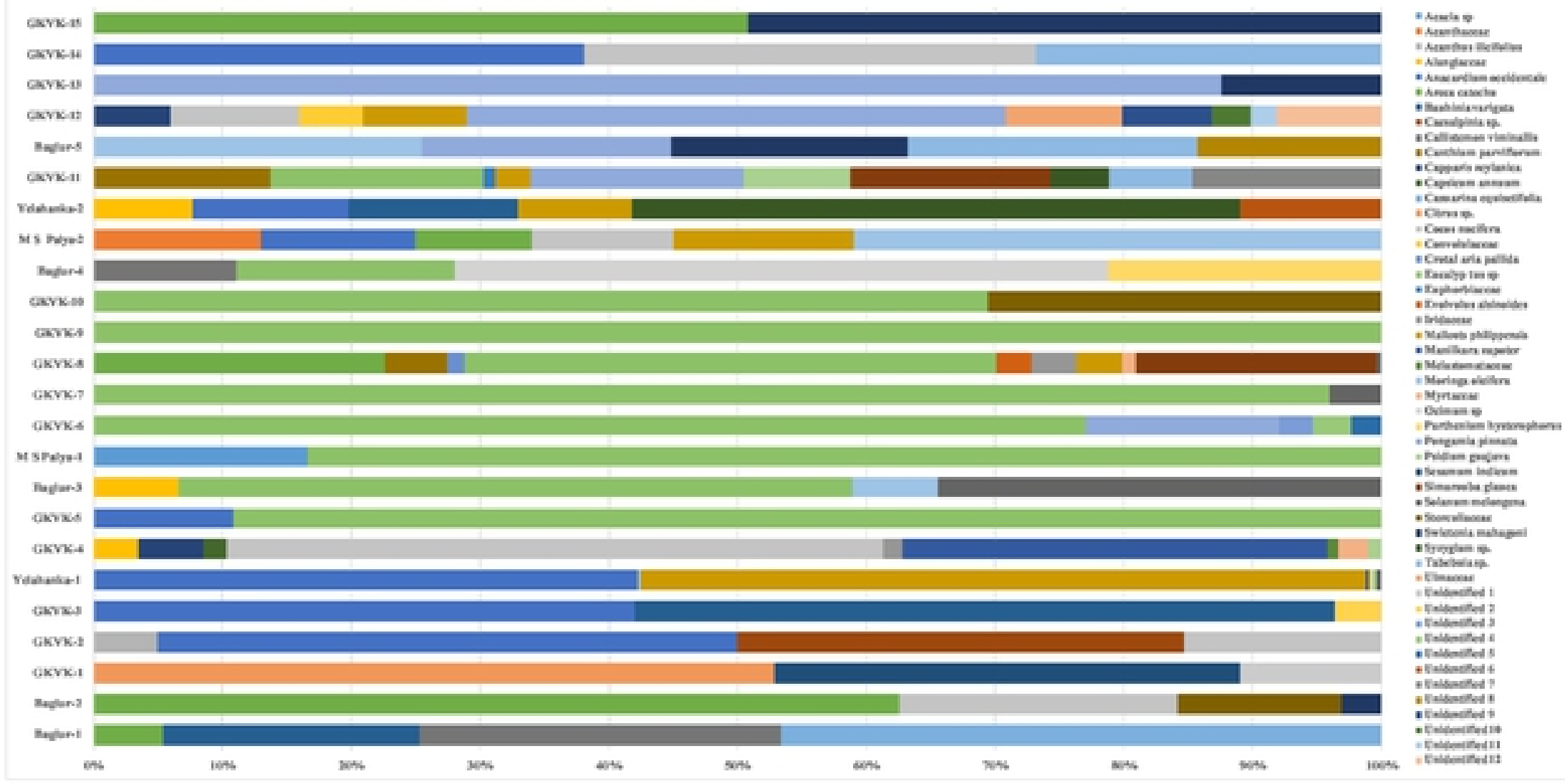

Figure 9: Percent frequency of pollens recorded trough melissopalynological study 


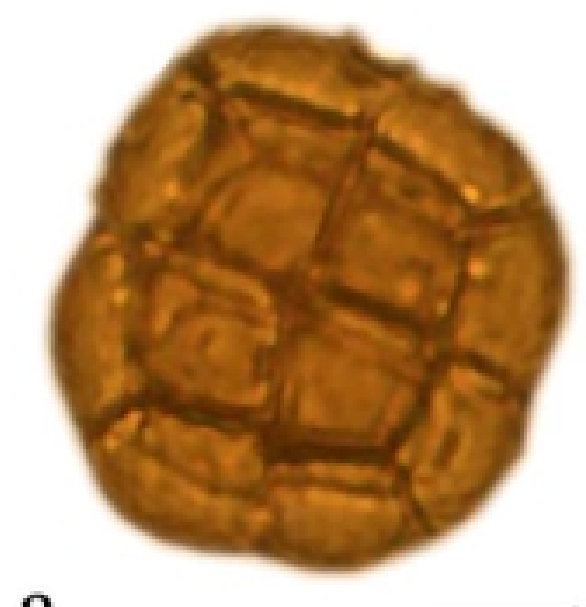

a bioRxiv preprint doi: $\mathrm{https} / / /$ doi.org/10.1101/2020.07.06.189274; this version posted July 6,2020 . The copyright holder for this preprint
(which was not certified by peer review) is the author/funder, who has granted bioRxiv a license to display the preprint in perpetuity. It is

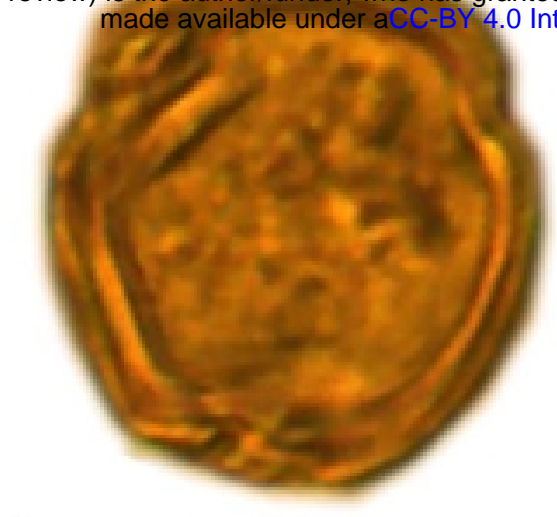

$\mathrm{d}$

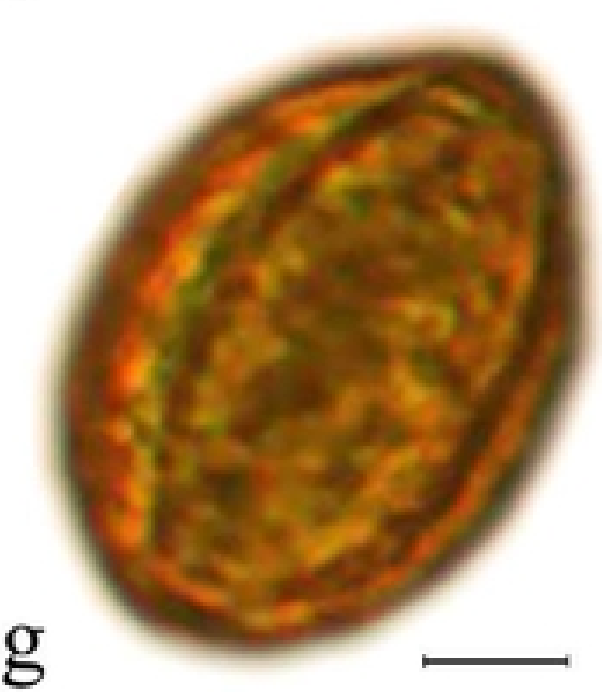

$\mathrm{g}$

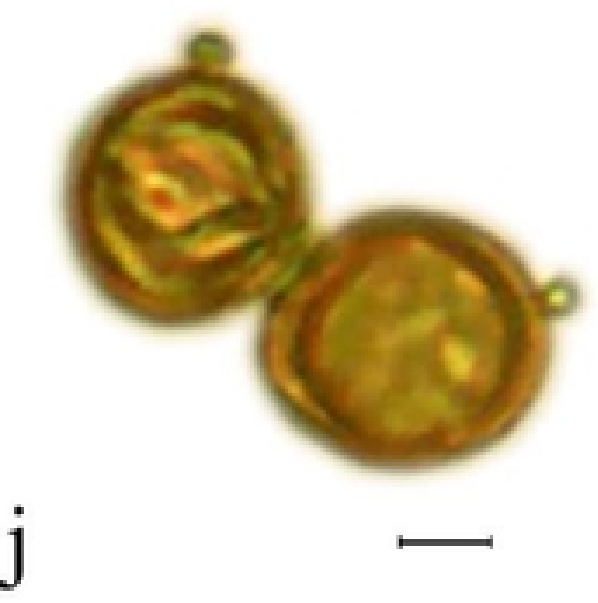

b

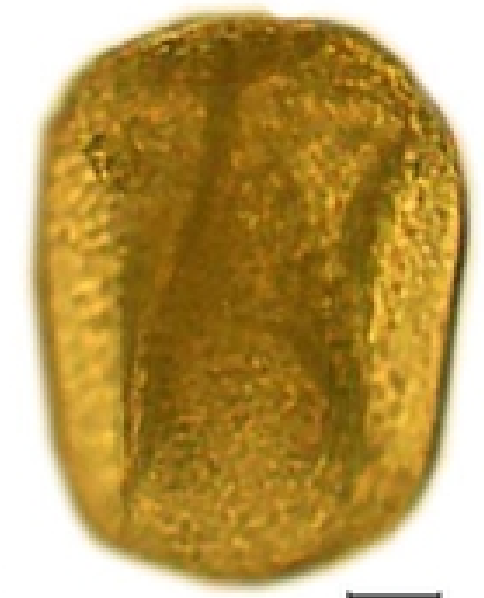

$\mathrm{e}$
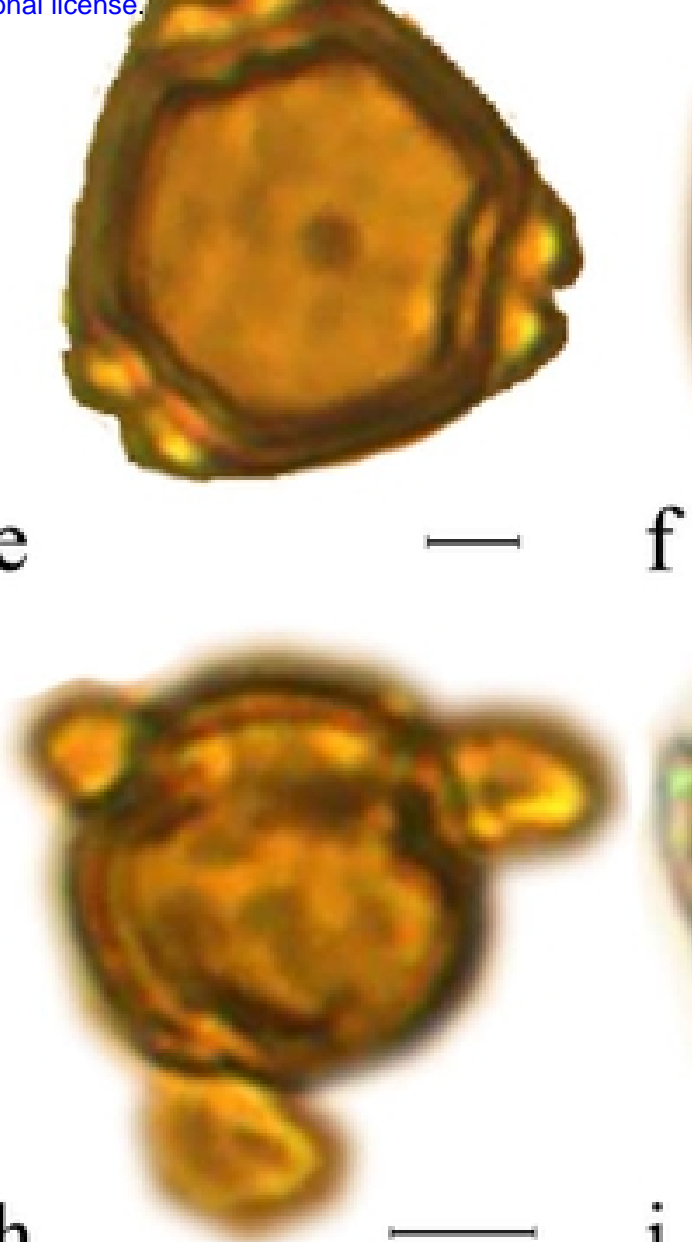

$\mathrm{h}$

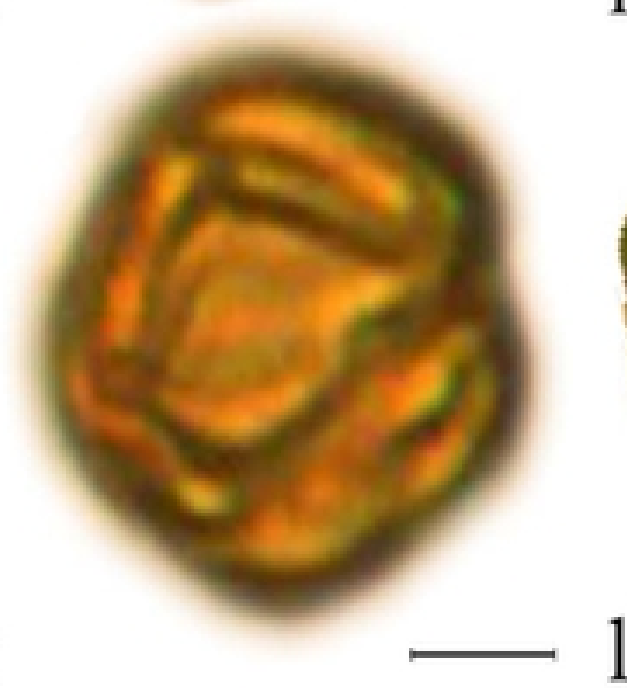

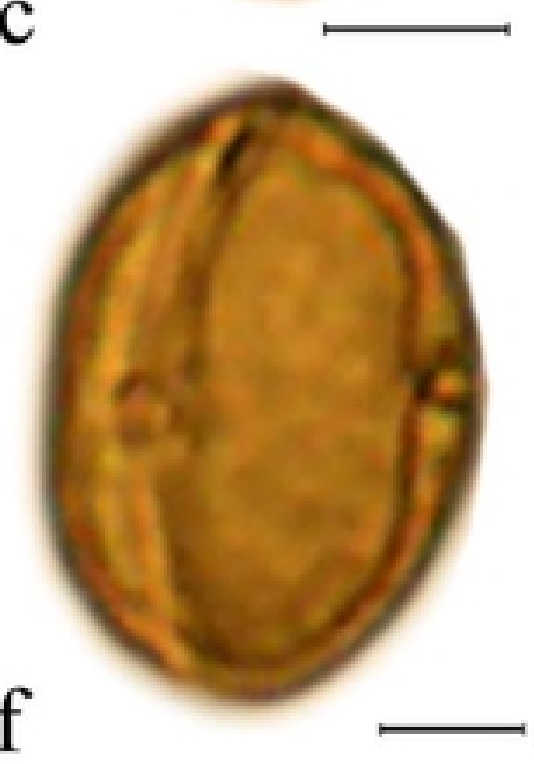
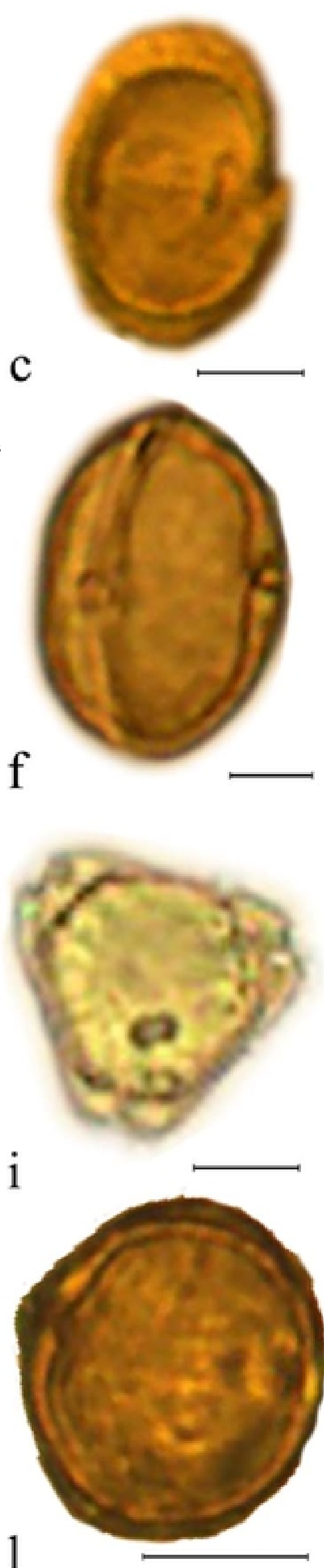

Figure. 10. Photomicrographs of pollen grains from the honey samples. a. Acacia sp. L'Her. (C.Mart.), b. Acantheceae, c. Acanthus ilicifolius L, d. Alangiaceae, c. Anacardium occidentale L., f. Areca catechu L., g. Bauhinia varigata $\mathrm{L} ., \mathrm{h}$. Caesalpinia sp. i. Callistemon viminalis Byrnes, j. Canthium parviflorum Roxb, $\mathrm{k}$. Capparis zeylanica $\mathrm{L}$., 1. Capsicum annuum $\mathrm{L}$. 

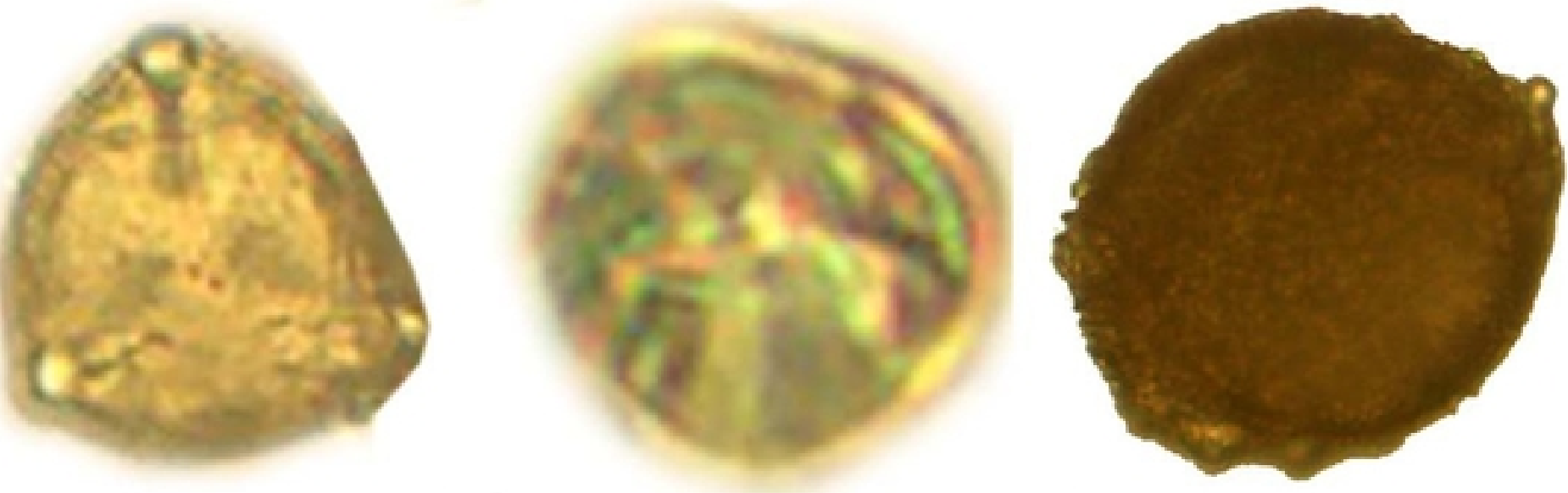

a

$\mathrm{b}$

$\mathrm{C}$

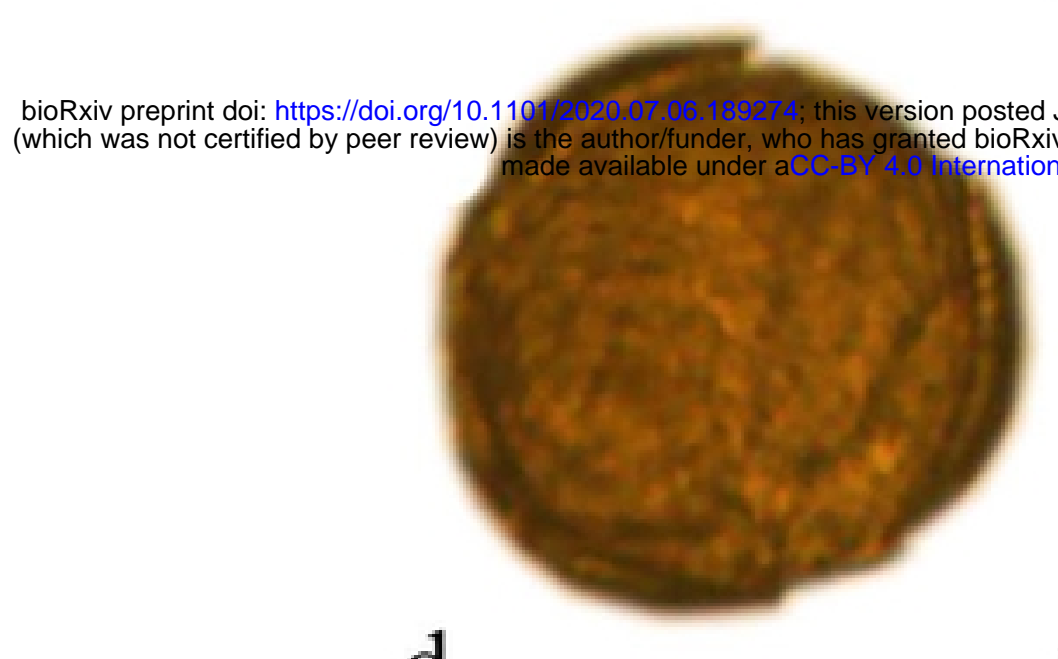

d

e
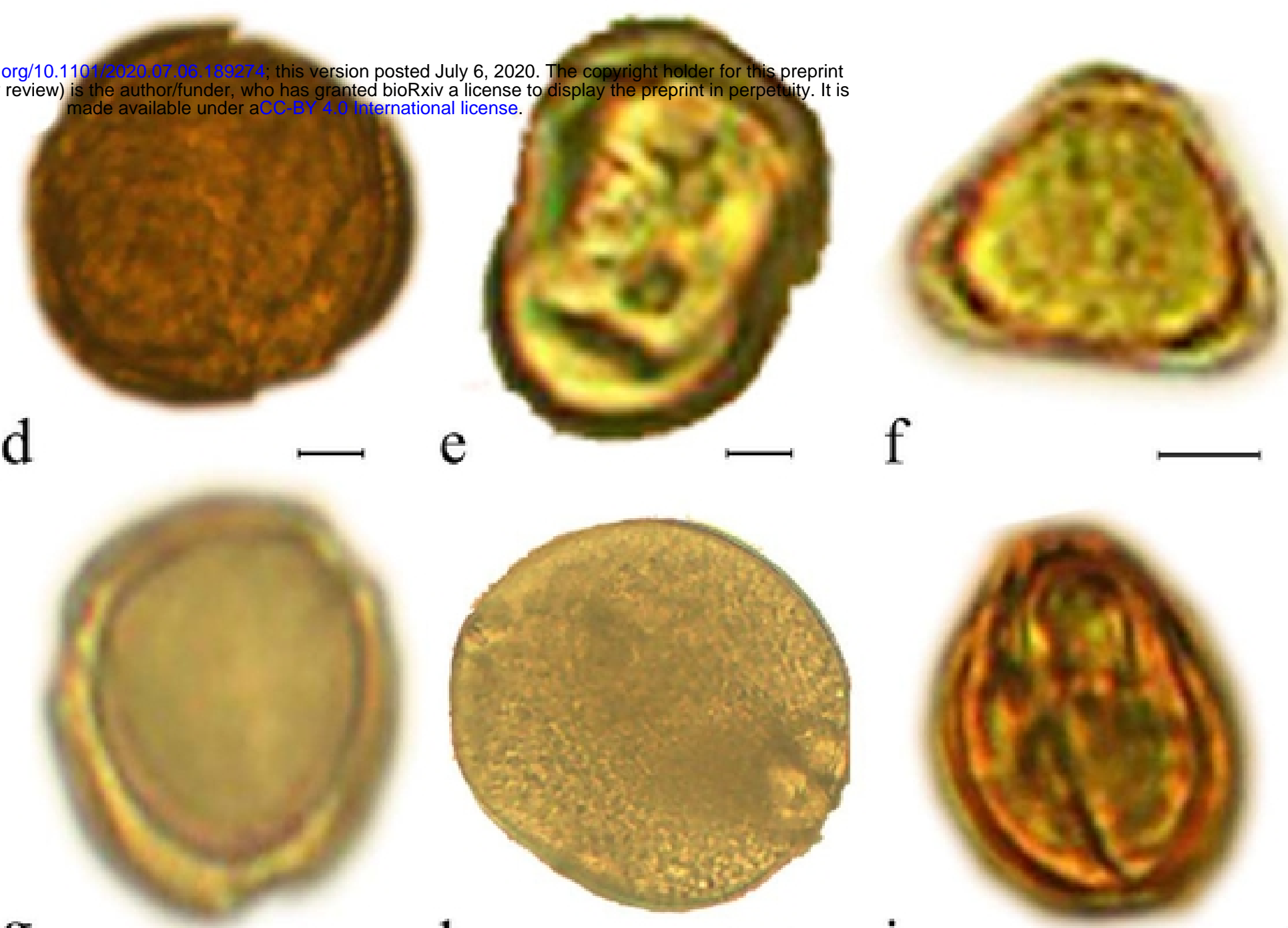

g

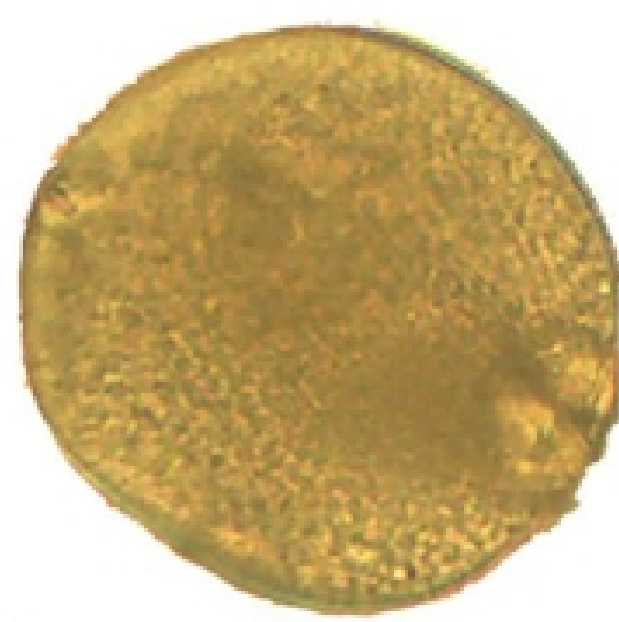

$\mathrm{h}$
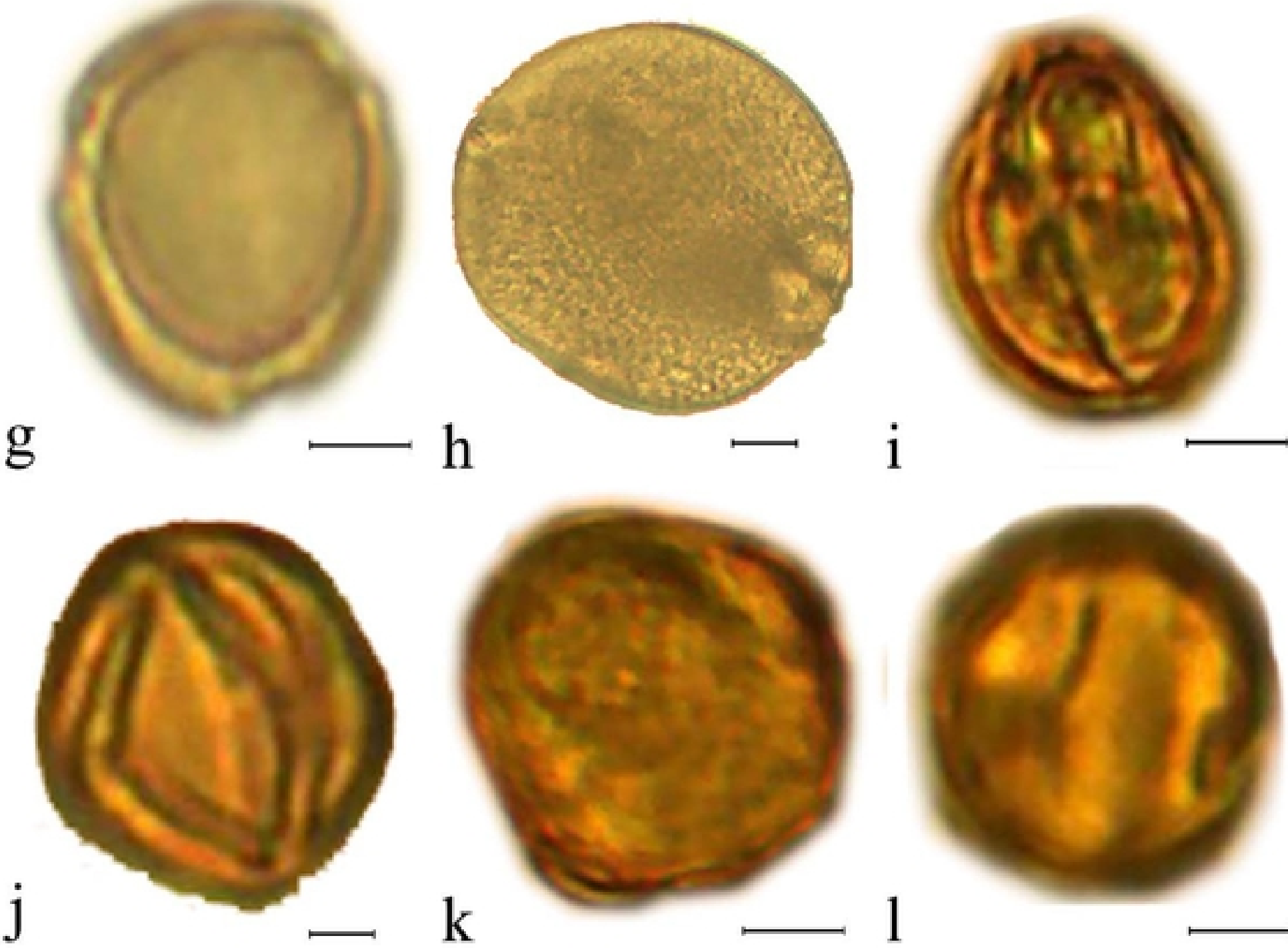

Figure 11. Photomicrographs of pollen grains from the honey samples (Continued).a. Casurina equisetifolia, b. Citrus sp., c. Cocos nucifera L., d. Convolulaceae, e. Crotalaria pallida L., Eucalyptus sp., g. Euphorbiaceae, h. Evolvulus alsinoides L., i-j. Irideaceae, k. Mallotus philippensis Lour., 1. Manilkera zapota. 

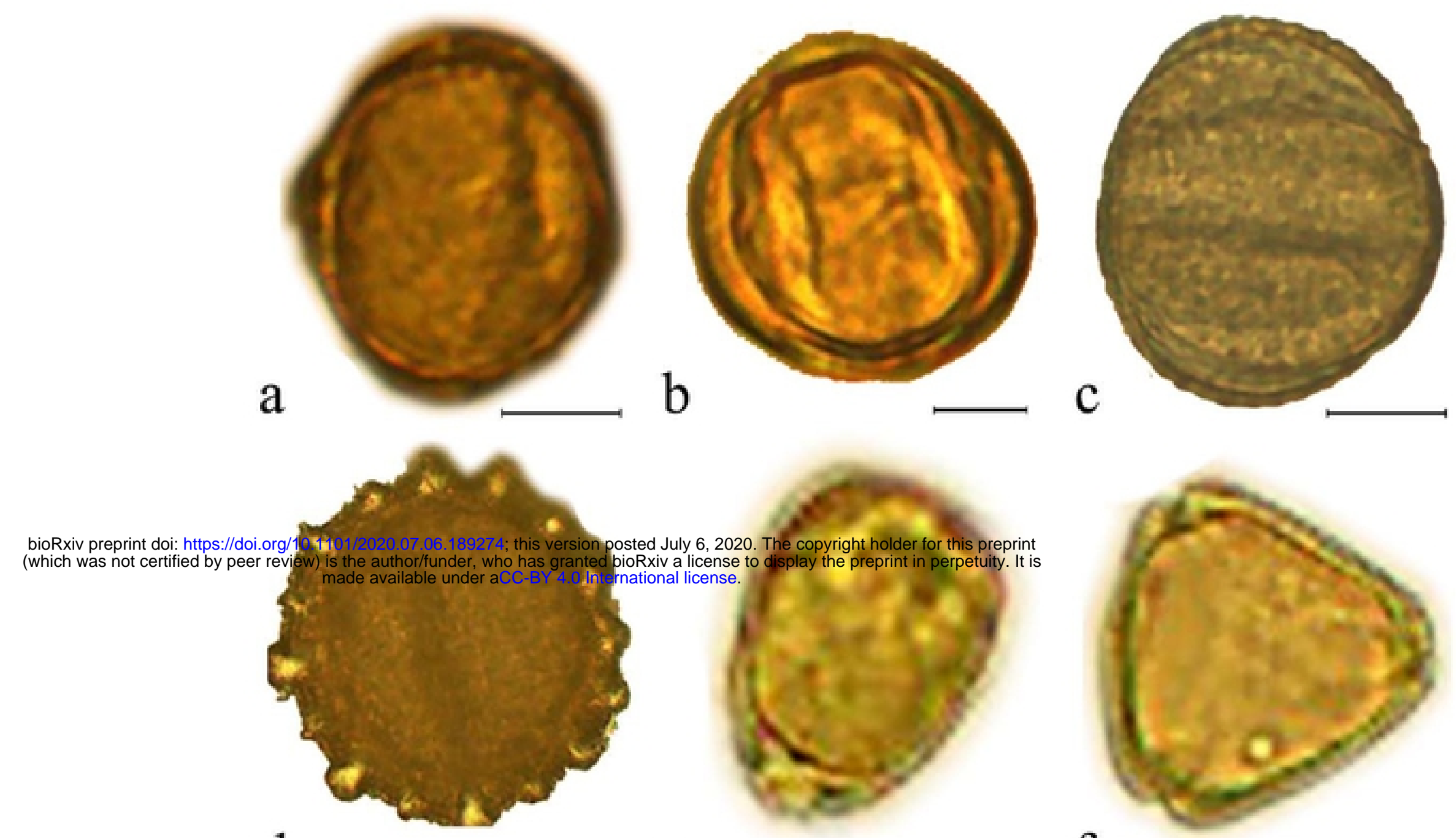

d

e

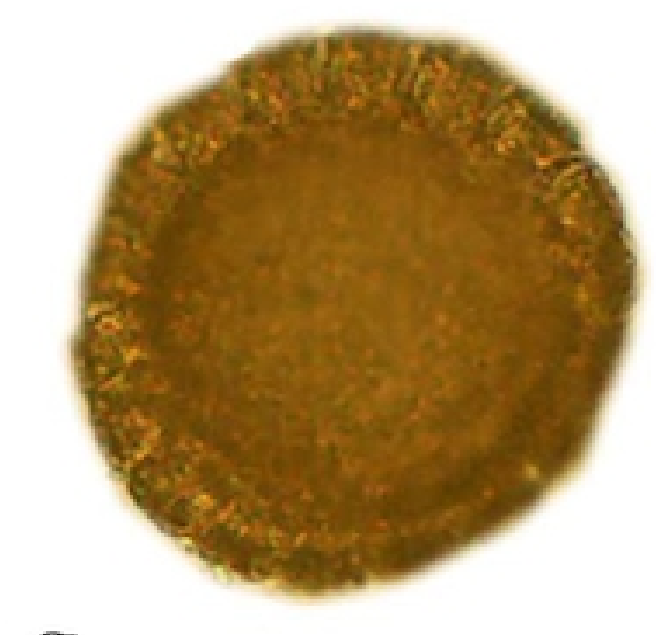

g

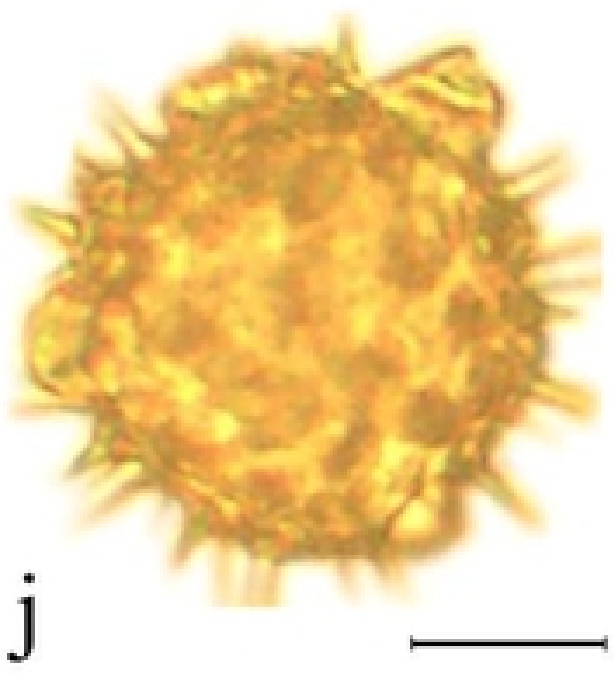

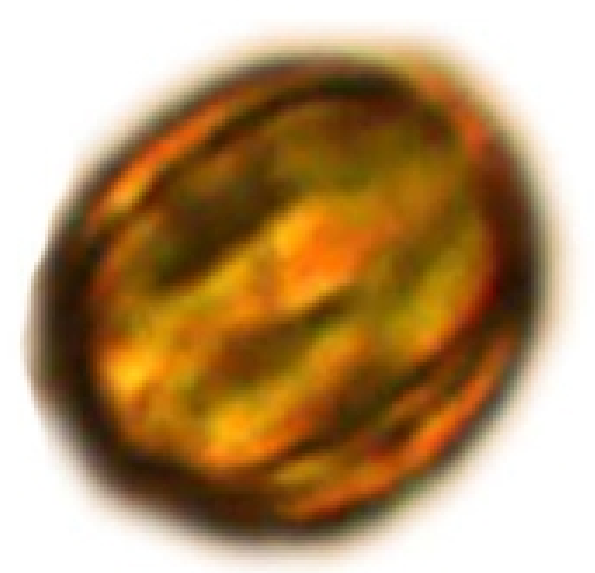

$\mathrm{h}$

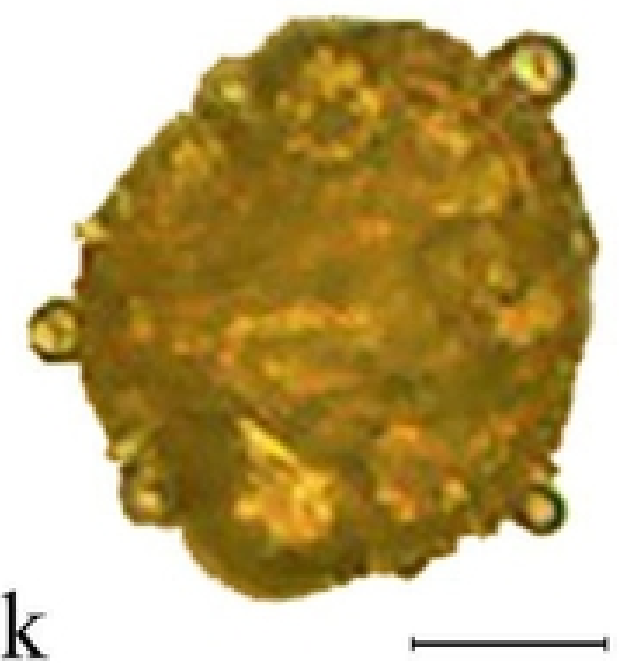

$\mathrm{C}$

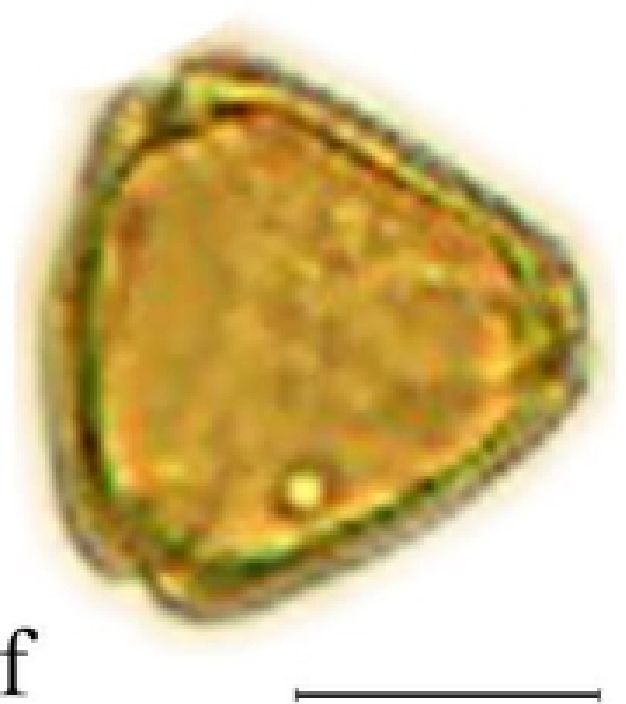

f

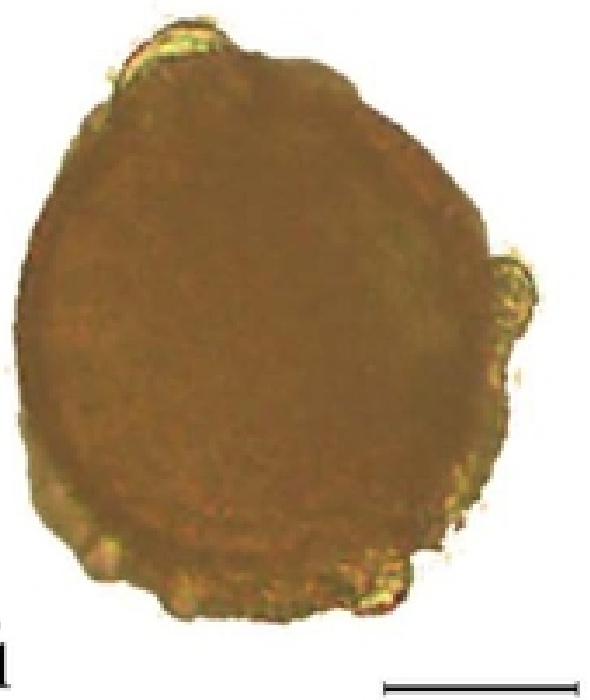

1

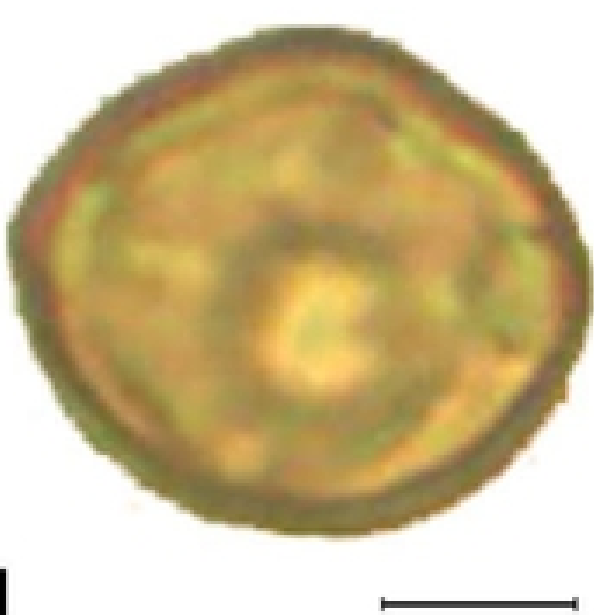

Figure 12. Photomicrographs of pollen grains from the honey samples (Continued). a. Melastomataceac, b.

Moringa oleifera L., c. Ocimum sp. L., d. Parthenium hysterophorus L., c. Pongamia pinnata L., f. Pisidium guajava L., g. Sesamum indicum DC., h. Simarouba glauca DC., i. Solanum melongena L., j. Sterculaceae, h. Suregada multiflora Baill, j. Swietenia mahagoni Lam 

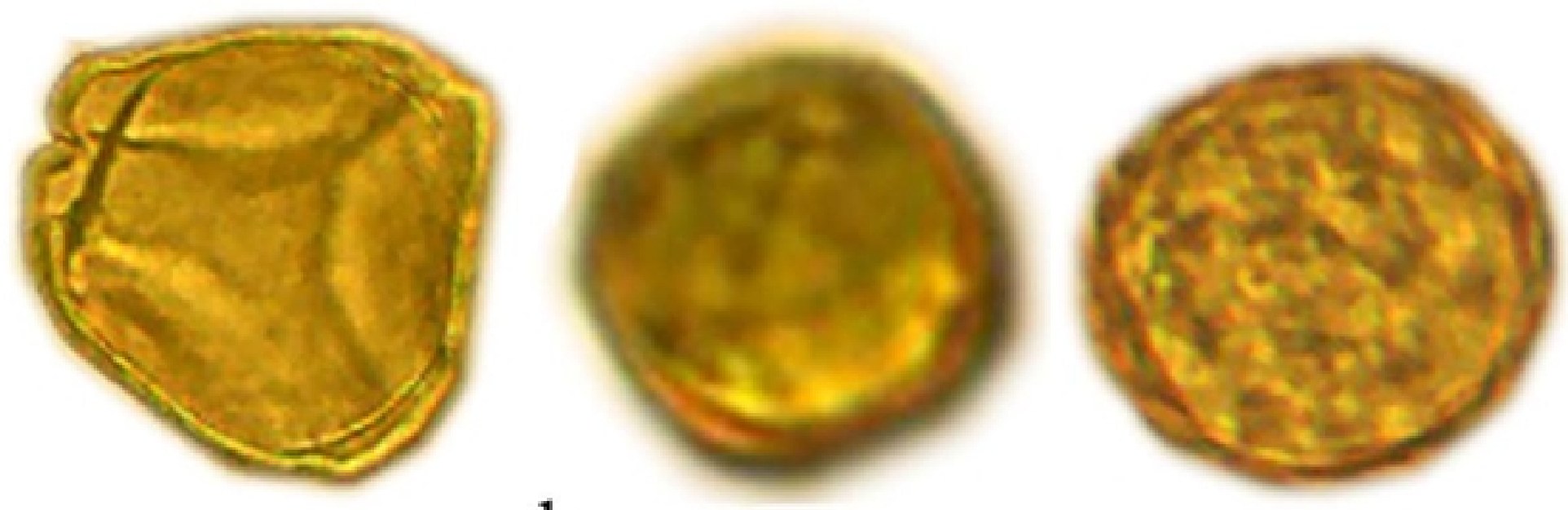

d

$\mathrm{b}$

C

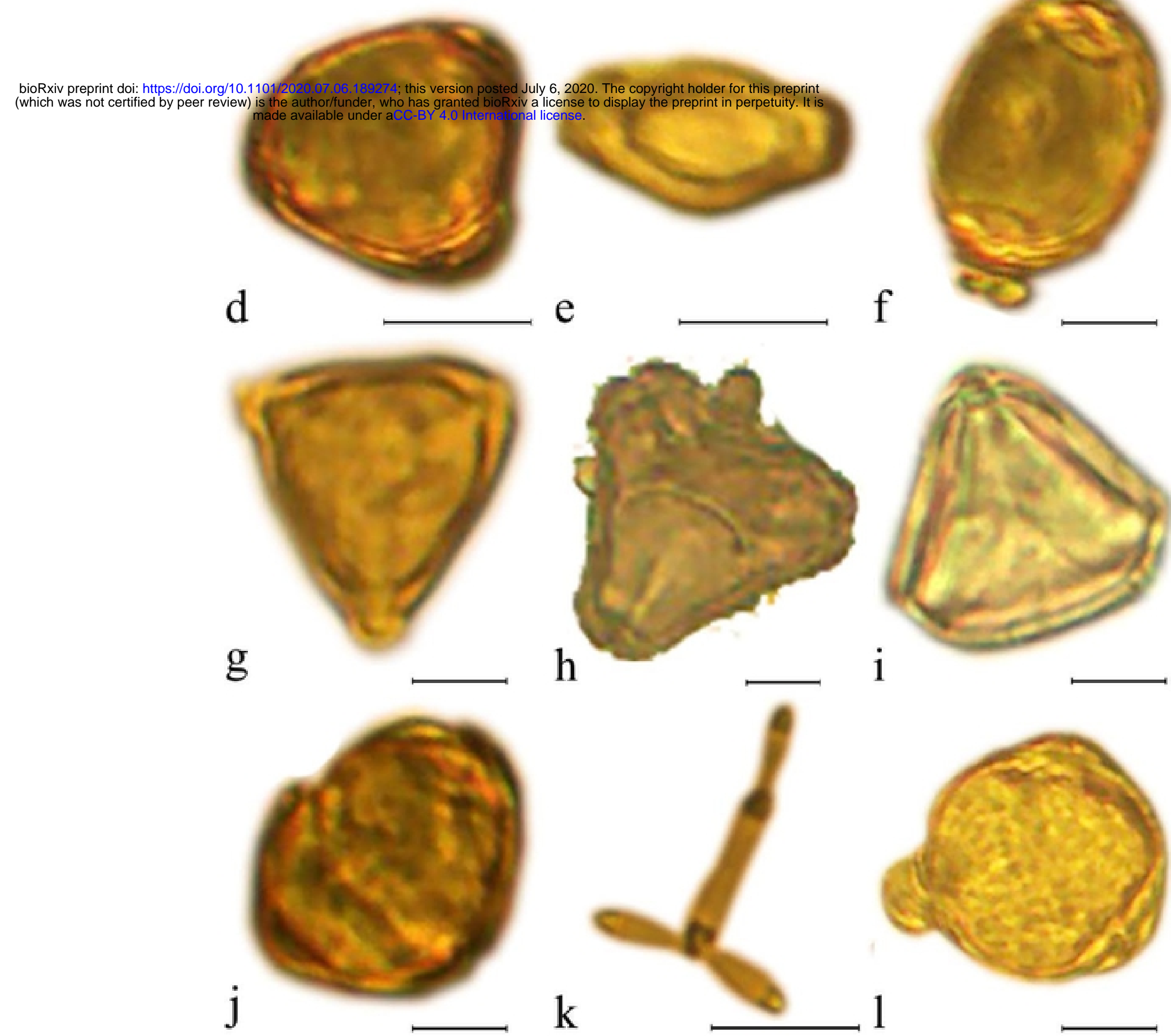

Figure 13. Photomicrographs of pollen grains from the honey samples (Continued).a. Syzygium cumini R.Br.,

b. Tabebuia sp. L., c. Ulmaceae, d-k. Unidentified 

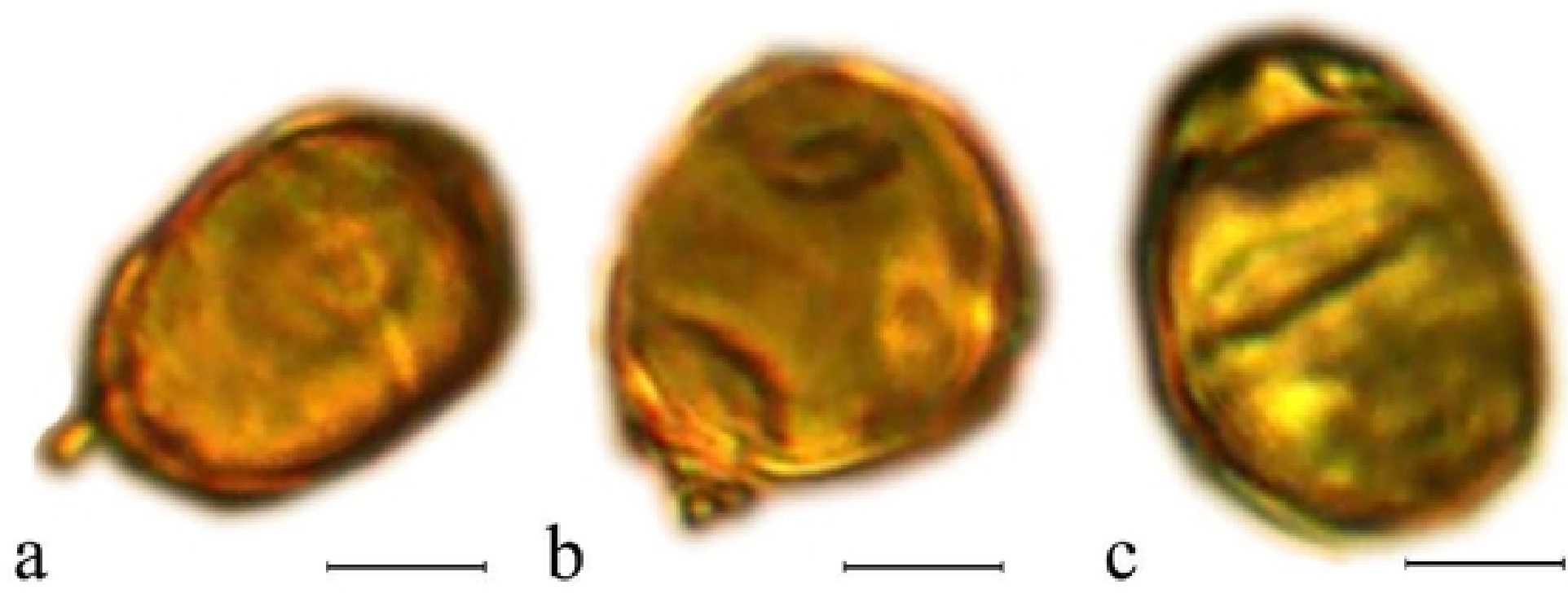

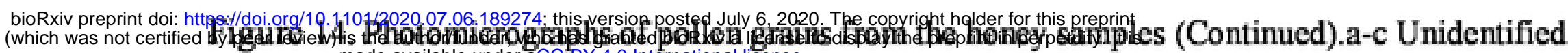
made avaliable under aCC-BY 4.0 international icense. pollen 